\title{
Evolution of diagenetic conditions and burial history in Buntsandstein Gp. fractured sandstones (Upper Rhine Graben) from in-situ $\delta^{18} O$ of quartz and ${ }^{40} \mathrm{Ar} /{ }^{39} \mathrm{Ar}$ geochronology of K-feldspar overgrowths
}

\author{
Claire Bossennec $^{1,2} \circledast$. Yves Géraud ${ }^{1} \cdot$ Johannes Böcker $^{3} \cdot{\text { Bernd } \mathrm{Klug}^{3} \cdot \text { Luca Mattioni }^{4} \cdot \text { Jean-Pierre Sizun }}^{5}$. \\ Masafumi Sudo ${ }^{6} \cdot$ Isabelle Moretti ${ }^{7,8,9}$
}

Received: 27 July 2020 / Accepted: 23 June 2021 / Published online: 9 July 2021

(c) The Author(s) 2021

\begin{abstract}
In-situ $\delta^{18} \mathrm{O}$ measured in the quartz overgrowths help identify temperature and fluid origin variations responsible for cementation of the pore network (matrix and fracture) in the Buntsandstein Gp. sandstone reservoirs within the Upper Rhine Graben. The overgrowths record two types of the evolution of $\delta^{18} \mathrm{O}: 1$ ) a monotonous decrease of the $\delta^{18} \mathrm{O}_{\text {overgrowth }}$ interpreted as linked to an increasing burial temperature and 2) random fluctuations, interpreted as pointing out the injection of allochthonous fluids in faulted areas, on the cementation processes of the pore network (both intergranular and fracture planes). Fluids causing the quartz cementation are either autochthonous buffered in ${ }^{18} \mathrm{O}$ from clay illitisation; or allochthonous fluids of meteoric origin with $\delta^{18} \mathrm{O}$ below $-5 \%$. These allochthonous fluids are in thermal disequilibrium with the host sandstone. The measured signal of $\delta^{18} \mathrm{O}_{\text {overgrowth }}$ measured from samples and calculated curves testing hypothetic $\delta^{18} \mathrm{O}_{\text {fluid }}$ are compared to $\mathrm{T}-\mathrm{t}$ evolution during burial. This modelling proposes the initiation of quartz cementation during the Jurassic and is validated by the in-situ ${ }^{40} \mathrm{Ar} /{ }^{39} \mathrm{Ar}$ dating results obtained on the feldspar overgrowths predating quartz overgrowths. A similar diagenetic history is recorded on the graben shoulders and in the buried parts of the basin. Here, the beginning of the pore network cementation predates the structuration in blocks of the basin before the Cenozoic graben opening.
\end{abstract}

Keywords Quartz cementation · Feldspar overgrowths · In situ $\delta^{18} \mathrm{O}$ microanalysis · Burial modelling · Buntsandstein Gp. Upper Rhine Graben

Claire Bossennec

claire.bossennec@tu-darmstadt.de

1 Université de Lorraine, GeoRessources, 54000 Nancy, France

2 Geothermal Science and Technology, Technical University of Darmstadt, 64287 Darmstadt, Germany

3 Neptune Energy Deutschland GmbH, Lingen, Germany

4 IFPEN, Rueil-Malmaison, France

5 UMR 6249, ChronoEnvironnement, Université de Bourgogne Franche-Comté, Besancon, France

6 Institut Für Geowissenschaften, Universität Potsdam, Postdam-Golm, Germany

7 ENGIE S.A, Courbevoie, France

8 Present Address: E2S, UPPA, Paris, France

9 Present Address: UPMC, Paris, France

\section{Introduction}

Cementation is a crucial feature of sandstone reservoir quality and was the topic of numerous studies (Houseknecht 1984; McBride 1989; Lundegard 1992; Bjørlykke and Egeberg 1993) and is still the focus of recent studies (Fischer et al. 2013; Bjørlykke 2014; El-Khatri et al. 2015; Henares et al. 2016; Yuan et al. 2017; Schmidt et al. 2020). Quartz overgrowths can be important authigenic minerals in deeply buried sandstones. Thus, triggered by fluid flow and compaction, the development of quartz overgrowths may reduce the initial porosity and impact permeability (Worden and Morad 2000; Götte et al. 2013; Therkelsen 2016). It is crucial to understand the pathways, timing, and origin(s) of the fluid(s) responsible for quartz cementation to improve diagenetic heterogeneity prediction in reservoirs. In-situ stable oxygen isotope geochemistry analysis can help to improve the understanding of the origin of clastic sediments and their post-depositional history by supplying information on 
(1) composition of the detrital grains; (2) composition of quartz cement; and (3) composition of diagenetic fluids and temperature of cementation (Götze et al. 2012; Hyodo et al. 2014; Pollington et al. 2011).

The nature and temperature of fluids flowing in faults are strongly impacting the properties and mineralogy of rock volumes in the vicinity of faults, especially the permeability distribution in petroleum and geothermal reservoirs, which may additionally result in reservoir compartmentalisation (Labaume and Moretti 2001; Brockamp and Clauer 2005; Faulkner et al. 2010; Aretz et al. 2015; Navelot et al. 2018).

The reconstruction of the paleo-water composition and the flow conditions inside the formation in this context is a challenge due to the uncertainties on the parameters which can control the onset of quartz cementation in sandstones:

(1) Fluid isotope composition (Valley and Graham 1996; Pollington et al. 2011; Yuan et al. 2017).

(2) Temperature (Walderhaug 1994; Marfil et al. 1996; Worden and Morad 2000; Sharp et al. 2016).

(3) Local fluid-rock interactions (including the presence of clay mineral grain coatings) (Bjørkum et al. 1998; Fisher et al. 1999; El-Khatri et al. 2015; Zhu et al. 2015).

K-feldspar overgrowths are also common in sandstones (Sizun 1995; Worden and Burley 2003). They usually have a slightly different chemical composition than the detrital feldspars, leading to differential chemical reactivity and stability during diagenesis (Sizun 1995; Mark et al. 2006; Milovský et al. 2012). Diagenetic K-feldspars are not limited to early diagenesis and shallow burial depth (Mark et al. 2005), and their dating can improve the understanding of the burial history (Mark et al. 2006).

The Buntsandstein Gp. sandstones are one of the primary targets for geothermal and hydrocarbon resource production in the Upper Rhine Graben due to their porosity (both fracture and intergranular porosity) and relatively high permeability (Haffen et al. 2015; Böcker et al. 2016; Kushnir et al. 2018; Vidal and Genter 2018). As the flow pathways in these sandstones are composed of 1) large fault pathways and 2) intergranular pore and fracture network, it is essential to have an integrated overview of the conditions of formation and distribution of quartz overgrowths at the basin scale. This approach must consider the plumbing complexity leading to the present-day situation and should be associated with various fluid-flow phases.

In this study, we focus on the nature of fluids and their temperature. The other parameters, i.e., the initial porosity and the surface available for cementation, are not the focus of this study. The effect of pressure on quartz cementation has been investigated by several authors and is considered of secondary importance (Bjørlykke and Egeberg 1993; Worden and Morad 2000).

Burial temperatures reached by the sandstones can be estimated to assess a credible fluid source. The chosen strategy consists of the modelling of several hypotheses on the fluid isotopic signature and temperature regime. This strategy was chosen as the tool of fluid inclusions is, in this case, not available. Fluid inclusions in the studied quartz overgrowth are very sparse and too small to perform thermometry and further fluid analysis.

$\mathrm{K}-\mathrm{Ar}$ ages on authigenic illite within the Buntsandstein $\mathrm{Gp}$. sandstones reveal illitisation events in the Late Jurassic, recorded in several locations (Meyer et al. 2000; Brockamp and Clauer 2005; Blaise et al. 2016). Some of these illitisation events with varying isotopic composition are reported as related to hydrothermal fluid flow (with a fluid temperature above $200^{\circ} \mathrm{C}$ ) within fault zones and others related to burial diagenesis. The remaining questions are the timing of these phases, how fluid flows within the sandstones, and how it interacts and affects reservoir cementation and compartmentalisation. Here, these aspects are considered, as samples located in the vicinity of major faults were investigated and compared with other samples located away from large fault zones. Burial T-t models propose explanations for the isotopic signatures of diagenetic overgrowths.

We aim to address three research objectives: (1) the provenance of detrital grains; (2) the timing of diagenetic reactions; and (3) the provenance, nature, and flow pathways within the Buntsandstein Gp. sandstones. After focusing on the geological complexity to define the burial model, we present the oxygen isotope composition of quartz grains and overgrowths and ${ }^{40} \mathrm{Ar} /{ }^{39} \mathrm{Ar}$ geochronology on detrital K-feldspar grains and overgrowths. The results are integrated into the pragenetic sequence to discuss the fluid origin, temperature, and timing of diagenetic processes. Subsequently, we propose a novel interpretation of the Buntsandstein Gp. fluid flow history, integrating the key role of plumbing, i.e., major faults and fracture and pore network features.

\section{Geological background}

The Upper Rhine Graben (URG) is a widely studied example of a syn-orogenic continental foreland rifting (Illies 1972; Bergerat 1987; Ziegler 1992; Merle and Michon 2001; Edel et al. 2007; Ford et al. 2007; Bourgeois et al. 2007). This extensional basin was formed by complex, large-scale structural features, which strongly affected the organisation of syn-rift sedimentary systems (Schumacher 2002; Derer et al. 2005; Roussé 2006). 


\section{Structural features}

The URG belongs to the central part of the European Cenozoic Rift System (ECRS), extending from the North Sea to the Mediterranean, over more than $1000 \mathrm{~km}$ (Illies 1972; Ziegler 1992; Ziegler et al. 1995). Today, the Vosges and Black Forest Massifs constitute the western and eastern shoulders of the rift, respectively. The URG is bordered in its northern part by the Rhenish Massif and in the South by the Jura Massif (Fig. 1A). This basin is oriented NNE/SSW and segmented into several sub-basins (Schumacher 2002). Transfer zones inherited from preexisting variscan lineaments separate these sub-basins (Derer et al. 2005).

\section{Pre-rift tectono-sedimentary history}

The pre-rift tectono-sedimentary context is complex (Fig. 2A). The targeted sandstones belong to the Buntsandstein Gp. dates from the Late Permian to Early Triassic (Induan-Olenekian) (Bourquin et al. 2006, 2007). The Buntsandstein Gp. sandstones were deposited in a fluvial and playa-lake system, which was covering the Variscan basement and Permo-Carboniferous NE striking basins at the southern border of the Western Germany sag basin (Bourquin et al. 2006, 2009; Soyk 2015). The area of the future
URG was subsiding from the Triassic to the Jurassic (Ziegler 1990, 1992). This phase was followed by an uplift-erosion phase from the Cretaceous to Early Eocene, which resulted in a SE dip of the Mesozoic series. The main uplift area was probably formed NW-NNW from the central URG and associated with synchronous volcanism (75-50 Ma) in the Rhenish Massif. This uplift was also contemporaneous to a long-wavelength folding episode of the lithosphere, related to the Alpine Tethys' geodynamical development (Ziegler et al. 2007; Bourgeois et al. 2007). Some studies suggest fault reactivations before the main Late Eocene subsidence episode, in association with volcanism on the northwestern margin of the Upper Rhine Graben, with the example of the Kisselwörth diatreme, which was ${ }^{40} \mathrm{Ar} /{ }^{39} \mathrm{Ar}$ dated to $55.8 \pm 0.2 \mathrm{Ma}$ (Lutz et al. 2013).

\section{Syn-rift tectono-sedimentary history}

The opening and development of the URG were contemporaneous with the collisional phases of the Pyrenean and Alpine orogeny (Schumacher 2002; Dèzes et al. 2004) (Fig. 2A).

The first stages of rifting started during a phase of regional uplift and volcanism during the Middle Eocene NW from the central URG (Volcanism in the Hocheifel at approx. 44-35 Ma (Lutz et al. 2013)), sedimentation started in mini
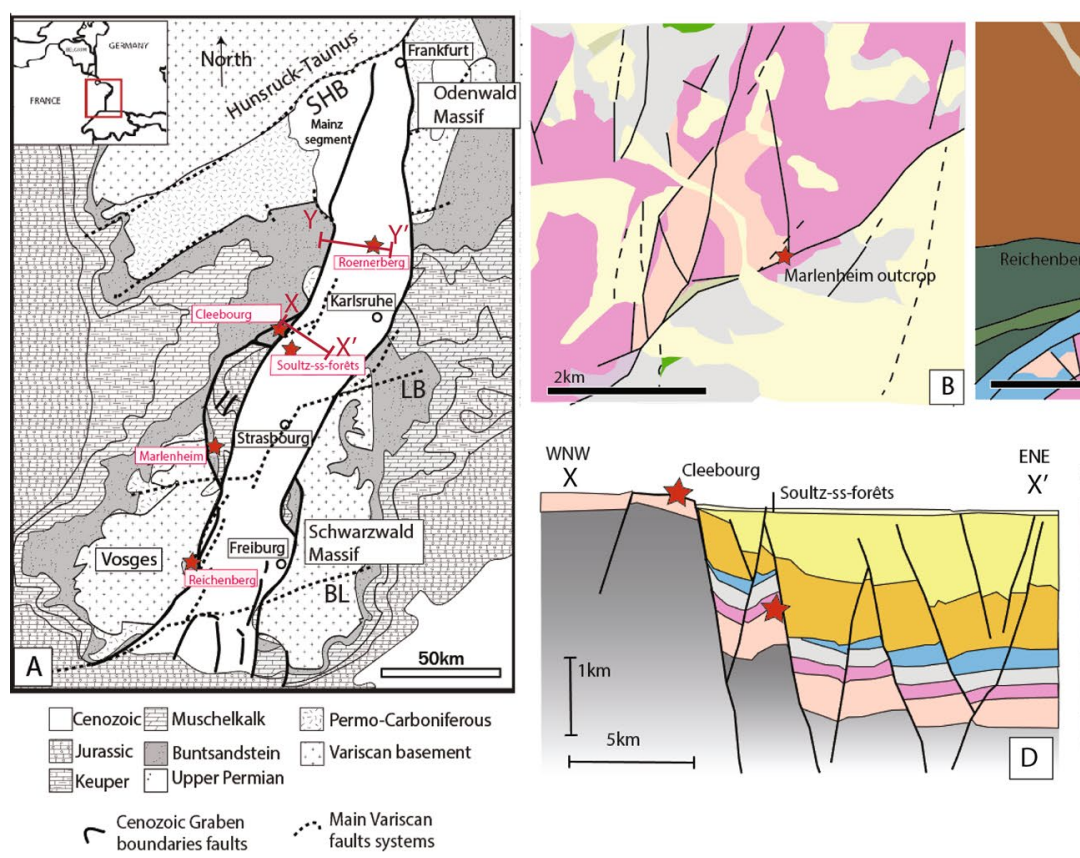
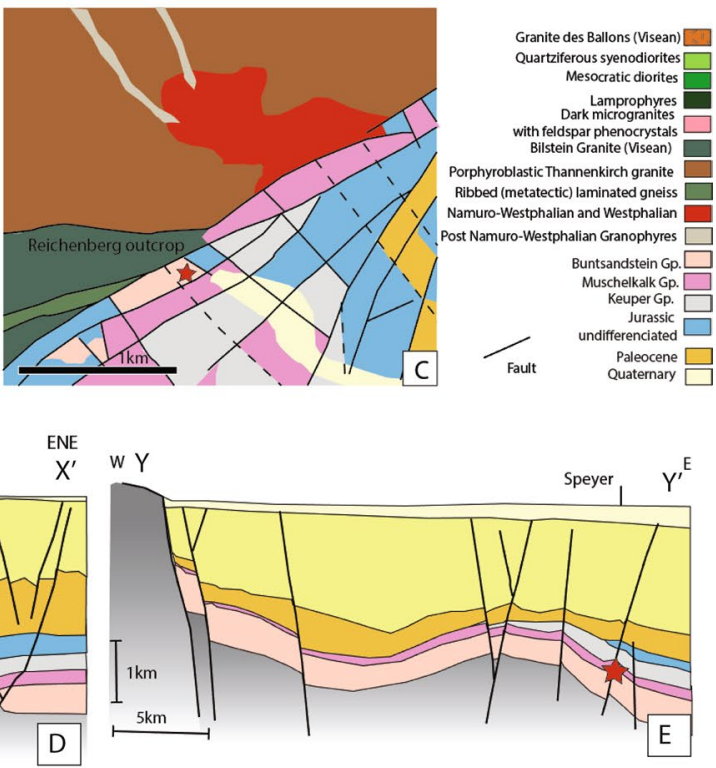

Paleocene $\square$
Fig. 1 Geological context and sampling localities: A Schematic geological map of the URG after Bossennec et al. (2018) and Eisbacher and Fielitz (2010) with sampled localities in pink. Major Variscan and Cenozoic faults are represented after Schumacher (2002). BL: Badenweiler-Lenzkirch fault system, LB: Lalaye-Lubine-BadenBaden fault system, SHB: South Hunsrück-Taunus Border fault system. B Local geological map of Marlenheim outcrop. C Local geological map of Reichenberg outcrop. D Schematic cross section ( modified from Sokol et al. (2013)) of the western border of the URG with the location of Cleebourg and Soultz sites (see Fig. 1 a) E Schematic cross section (modified from Sokol et al. (2013)) of the western border of the URG with location of Roemerberg wells 


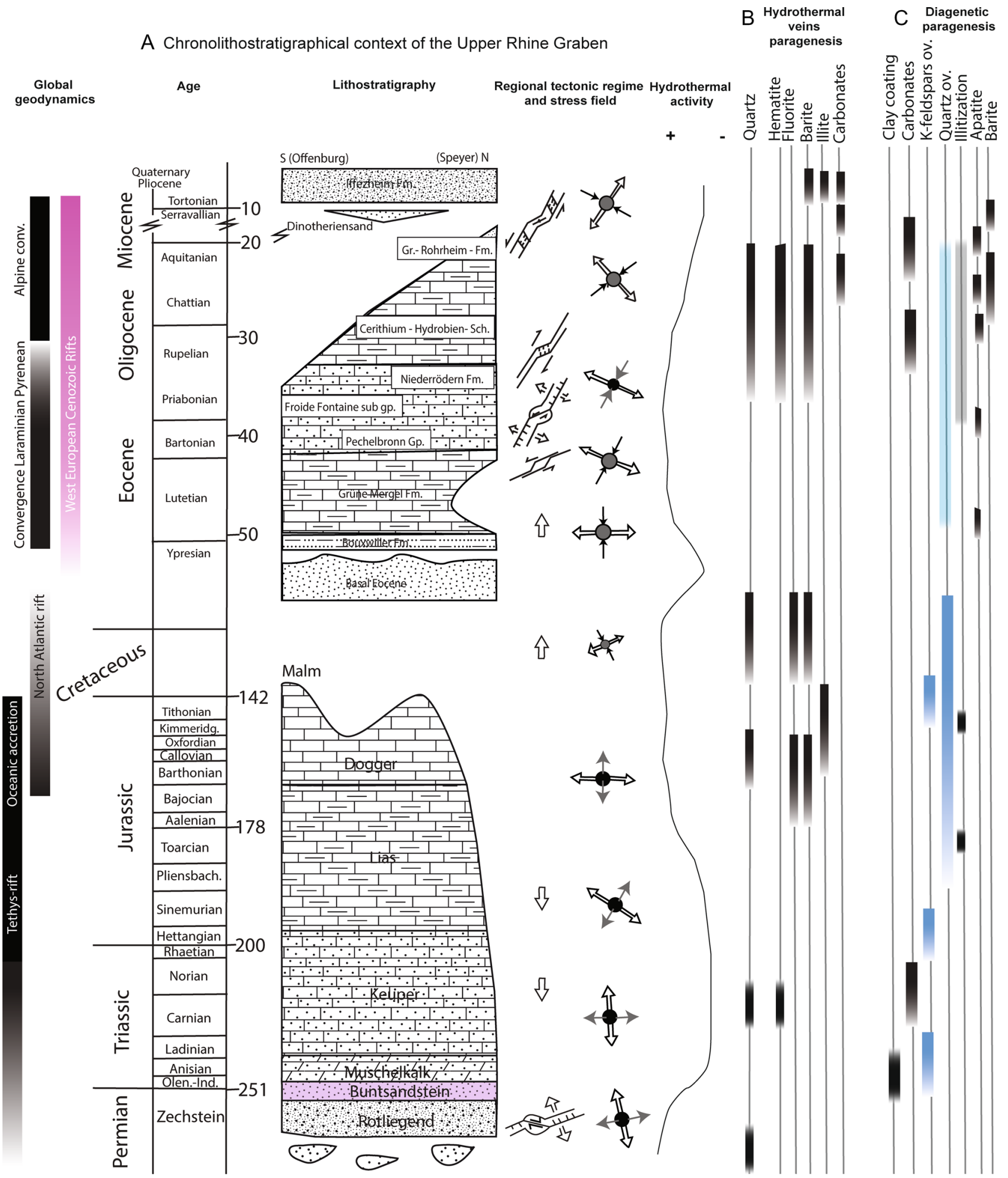

Fig. 2 A Chronological chart, modified after Böcker and Littke (2015) and Bossennec et al. (2018), placed in the frame of major geodynamical episodes. Paleostress orientations are represented in black for $\sigma 1$, grey for $\sigma 2$, and white for $\sigma 3$; regional stress fields and geodynamical context (Schumacher 2002; Blaise et al. 2016). The hydro- thermal activity is represented qualitatively (Walter et al. 2018). B Hydrothermal veins paragenesis synthesis (Pfaff et al. 2010; Staude et al. 2012; Bons et al. 2014; Burisch et al. 2017a, b). C Paragenetic sequence in Buntsandstein Gp. Sandstones (Soyk 2015) 
basins with an NE-SW orientation. These early rift basins, dated from the Late Ypresian-Lutetian, were filled with siliciclastic detrital products of the erosion of the uplifted graben shoulders evolving laterally to clay-limestones layers toward depocenters. (Roussé 2006; Eisbacher and Fielitz 2010).

From 46 to $37 \mathrm{Ma}$, with the increase of the basins sizes, sedimentation evolved into marly-bituminous clays, coals, and freshwaters limestones, characterising shallow lacustrine environments under a humid and warm climate (Sissingh 1998; Böcker et al. 2016). An increase in subsidence characterised the Late Eocene period. Marly and calcareous deposits belonging to the 'Grüne Mergel' member recorded first marine ingressions from the South (Meulenkamp and Sissingh 2003; Châteauneuf and Ménillet 2014). During the Oligocene, the area entered thermal subsidence, associated with a regional WNW-ESE extensional regime (Schumacher 2002; Berger et al. 2005). The whole basin was flooded by marine ingressions several times during the Rupelian, and the deposition of clayey organic-rich marls occurred even near the current graben margins. In the late Oligocene and Miocene, the regional stress regime changed to a transtensive sinistral shear. A new depocenter was established in the northern part of the URG, the Heidelberg-Mannheim Graben (Schumacher 2002). This new stress regime also developed a gradual uplift of the southern URG (Timar-Geng et al. 2006). A lithosphere folding event which began during the Burdigalian, at $17 \mathrm{Ma}$, caused the uplift of the southern URG (Dèzes et al. 2004; Ziegler et al. 2007; Bourgeois et al. 2007; Reicherter et al. 2008) and reactivated basement faults striking NE (Rotstein et al. 2005, 2006; Edel et al. 2007). A regional erosion of late Oligocene sediments occurred during the Middle Miocene uplift, giving the URG a geometry close to the current one. The northern URG underwent the third phase of subsidence from the Pliocene to Quaternary (Larroque and Laurent 1988; Schumacher 2002; Dèzes et al. 2004; Cloetingh et al. 2005). The lithospheric folding might also have played a role in the current geometry of the URG through crustal subsidence in the northern URG (Dèzes et al. 2004; Cloetingh et al. 2005, 2006).

\section{Fluid history}

During its complex burial history, Buntsandstein Gp. sandstones were exposed to varying temperature and fluids (regional hydrothermal activity, Fig. 2B), resulting in a multi-stage paragenetic sequence (Fig. 2C), strongly dependent on fault activity (Clauer et al. 2008; Dresmann et al. 2010; Blaise et al. 2016; Bossennec et al. 2018). The paragenetic sequence of the targeted sandstones is characterised by the first phase of diagenetic clay mineral grain coating, followed by the first generation of K-feldspar overgrowths. Quartz cementation is the third stage of the paragenetic sequence and is followed by an extensive illitisation, already documented within Lower Triassic sandstones in the Paris Basin (Blaise et al. 2016). In the meantime, several hydrothermal events are recorded regionally (Fig. 2B), with several pulses recorded within the underlying basement and with fault zones affecting the sedimentary deposits since the Triassic (Boiron et al. 2011; Loges et al. 2012; Walter et al. 2016, 2019; Dezayes and Lerouge 2019). Quartz, siderite, and barite mineralise in the fracture network linked to fault systems that were active during rift opening. This facture diagenesis suggests external fluid flow through the fracture network during Cenozoic hydrothermal events relative to the rift opening.

The focus of this study is to derive possible fluid sources affecting Buntsandstein Gp. sandstone diagenesis, their likely migration pathways and timing (Fig. 2C).

\section{Materials and methods}

\section{Sampling}

The samples were retrieved from different URG locations (Figs. 1, 3 and Table 1). All belong to the Buntsandstein Gp. sandstones but have varying burial histories. Samples from the URG shoulders (Marlenheim, Cleebourg, Reichenberg) were at their maximum burial depth during the Cretaceous. In contrast, samples currently located in deep-seated reservoirs reached their maximum burial during the Cenozoic. Samples divide into two categories: Category F) for samples having a fracture intensity ( $>4$ fractures. $\mathrm{m}^{-1}$ ) from within a fault zone; Category C) for "clean" samples with an undisturbed intergranular space which do not present deformation-related microstructural

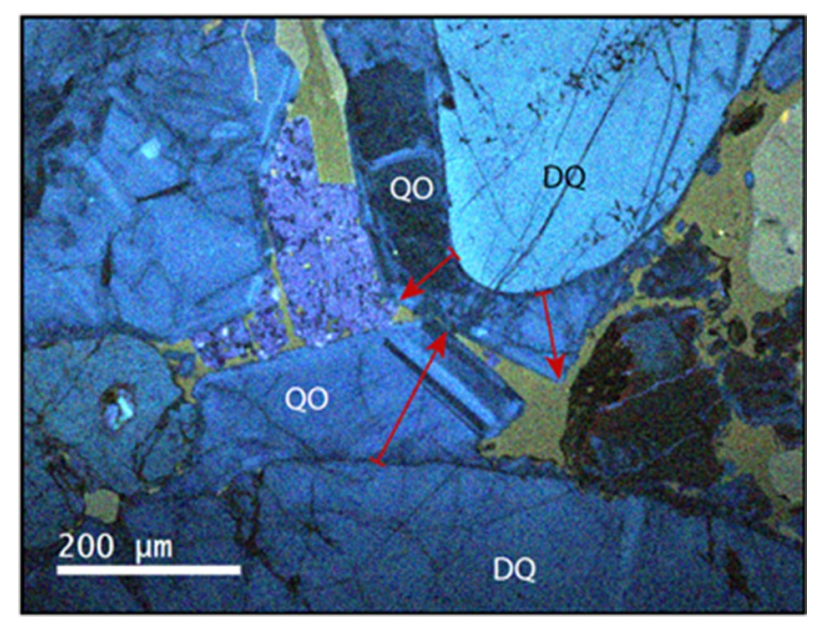

Fig. 3 Examples of profile measurements (red arrows) performed within detrital (DQ) and quartz overgrowths (QO) (SEM-CL) 
Table 1 Sample description, with location, host-rock, category, type of analyses performed, and burial sequence type

\begin{tabular}{|c|c|c|c|c|c|c|c|c|c|}
\hline \multirow[t]{2}{*}{ Location } & \multirow{2}{*}{$\begin{array}{l}\text { Coordinates } \\
\text { (WGS 84) }\end{array}$} & \multirow[t]{2}{*}{ Sample ID } & \multirow[t]{2}{*}{ Category* } & \multirow[t]{2}{*}{ Stratigraphy } & \multirow{2}{*}{$\begin{array}{l}\text { Sample type } \\
\text { (outcrop sam- } \\
\text { ple or borehole } \\
\text { core) }\end{array}$} & \multicolumn{2}{|l|}{ Analysis } & \multirow{2}{*}{$\begin{array}{l}\text { Maximum } \\
\text { burial depth } \\
\text { (m) }\end{array}$} & \multirow{2}{*}{$\begin{array}{l}\text { Burial } \\
\text { sequence } \\
\text { type }\end{array}$} \\
\hline & & & & & & Quartz isotopy & $A r / A r$ & & \\
\hline Roemerberg & $\begin{array}{c}49.326036 \mathrm{~N} \\
8.437686 \mathrm{E}\end{array}$ & A-2783 & $\mathrm{C}$ & $\begin{array}{l}\text { Upper Bunt- } \\
\text { sandstein }\end{array}$ & Borehole & $\mathrm{x}$ & & $\sim 2800$ & 3 \\
\hline Roemerberg & $\begin{array}{c}49.326036 \mathrm{~N} \\
8.437686 \mathrm{E}\end{array}$ & B-2882 & $\mathrm{C}$ & $\begin{array}{l}\text { Middle Bunt- } \\
\text { sandstein }\end{array}$ & Borehole & $\mathrm{x}$ & & $\sim 2800$ & 3 \\
\hline Roemerberg & $\begin{array}{r}49.326036 \mathrm{~N} \\
8.437686 \mathrm{E}\end{array}$ & C-2335 & $\mathrm{F}$ & $\begin{array}{l}\text { Upper Bunt- } \\
\text { sandstein }\end{array}$ & Borehole & & $\mathrm{x}$ & $\sim 2400$ & 3 \\
\hline Roemerberg & $\begin{array}{r}49.326036 \mathrm{~N} \\
8.437686 \mathrm{E}\end{array}$ & D-2537 & $\mathrm{F}$ & $\begin{array}{l}\text { Middle Bunt- } \\
\text { sandstein }\end{array}$ & Borehole & $\mathrm{x}$ & & $\sim 2500$ & 3 \\
\hline Roemerberg & $\begin{array}{r}49.326036 \mathrm{~N} \\
8.437686 \mathrm{E}\end{array}$ & E-2671 & $\mathrm{C}$ & $\begin{array}{l}\text { Upper Bunt- } \\
\text { sandstein }\end{array}$ & Borehole & $\mathrm{x}$ & & $\sim 2600$ & 3 \\
\hline Roemerberg & $\begin{array}{r}49.326036 \mathrm{~N} \\
8.437686 \mathrm{E}\end{array}$ & E-2948 & $\mathrm{C}$ & $\begin{array}{l}\text { Middle Bunt- } \\
\text { sandstein }\end{array}$ & Borehole & & $\mathrm{x}$ & $\sim 3000$ & 3 \\
\hline Roemerberg & $\begin{array}{c}49.326036 \mathrm{~N} \\
8.437686 \mathrm{E}\end{array}$ & F-3225 & $\mathrm{F}$ & $\begin{array}{l}\text { Middle Bunt- } \\
\text { sandstein }\end{array}$ & Borehole & $\mathrm{x}$ & $\mathrm{x}$ & $\sim 3200$ & 3 \\
\hline $\begin{array}{l}\text { Soultz-ss- } \\
\text { forêts }\end{array}$ & $\begin{array}{c}48.930772 \mathrm{~N} \\
7.866665 \mathrm{E}\end{array}$ & EPS11360 & $\mathrm{C}$ & $\begin{array}{l}\text { Middle Bunt- } \\
\text { sandstein }\end{array}$ & Borehole & $\mathrm{x}$ & & $\sim 2000$ & 2 \\
\hline $\begin{array}{l}\text { Soultz-ss- } \\
\text { forêts }\end{array}$ & $\begin{array}{r}48.930772 \mathrm{~N} \\
7.866665 \mathrm{E}\end{array}$ & EPS11379 & $\mathrm{C}$ & $\begin{array}{l}\text { Middle Bunt- } \\
\text { sandstein }\end{array}$ & Borehole & & $\mathrm{x}$ & $\sim 2000$ & 2 \\
\hline Cleebourg & $\begin{array}{c}49.013881 \mathrm{~N} \\
7.890718 \mathrm{E}\end{array}$ & K466 & $\mathrm{F}$ & $\begin{array}{l}\text { Lower Bunt- } \\
\text { sandstein }\end{array}$ & Outcrop & $\mathrm{x}$ & $\mathrm{x}$ & $\sim 1500$ & 1 \\
\hline Cleebourg & $\begin{array}{c}49.013881 \mathrm{~N} \\
7.890718 \mathrm{E}\end{array}$ & K308 & $\mathrm{C}$ & $\begin{array}{l}\text { Lower Bunt- } \\
\text { sandstein }\end{array}$ & Outcrop & & $\mathrm{x}$ & $\sim 1500$ & 1 \\
\hline Cleebourg & $\begin{array}{c}49.013881 \mathrm{~N} \\
7.890718 \mathrm{E}\end{array}$ & K500 & $\mathrm{C}$ & $\begin{array}{l}\text { Lower Bunt- } \\
\text { sandstein }\end{array}$ & Outcrop & & $\mathrm{x}$ & $\sim 1500$ & 1 \\
\hline Cleebourg & $\begin{array}{c}49.013881 \mathrm{~N} \\
7.890718 \mathrm{E}\end{array}$ & K352 & $\mathrm{F}$ & $\begin{array}{l}\text { Lower Bunt- } \\
\text { sandstein }\end{array}$ & Outcrop & & $\mathrm{x}$ & $\sim 1500$ & 1 \\
\hline Cleebourg & $\begin{array}{c}49.013881 \mathrm{~N} \\
7.890718 \mathrm{E}\end{array}$ & M11 & $\mathrm{F}$ & $\begin{array}{l}\text { Lower Bunt- } \\
\text { sandstein }\end{array}$ & Outcrop & & $\mathrm{x}$ & $\sim 1500$ & 1 \\
\hline Marlenheim & $\begin{array}{c}48.624017 \mathrm{~N} \\
7.474710 \mathrm{E}\end{array}$ & X009 & $\mathrm{C}$ & $\begin{array}{l}\text { Middle Bunt- } \\
\text { sandstein }\end{array}$ & Outcrop & $\mathrm{x}$ & & $\sim 1500$ & 1 \\
\hline Marlenheim & $\begin{array}{c}48.624017 \mathrm{~N} \\
7.474710 \mathrm{E}\end{array}$ & X024 & $\mathrm{F}$ & $\begin{array}{l}\text { Middle Bunt- } \\
\text { sandstein }\end{array}$ & Outcrop & $\mathrm{x}$ & & $\sim 1500$ & 1 \\
\hline Reichenberg & $\begin{array}{c}48.213951 \mathrm{~N} \\
7.337607 \mathrm{E}\end{array}$ & B002 & $\mathrm{F}$ & $\begin{array}{l}\text { Middle Bunt- } \\
\text { sandstein }\end{array}$ & Outcrop & $\mathrm{x}$ & & $\sim 1500$ & 1 \\
\hline
\end{tabular}

*C-Matrix sample; F-Fractured sample

features. For quartz overgrowths, samples X009 from Marlenheim (Fig. 1B) and B002 from Reichenberg (Fig. 1C) are selected from outcrops located on eastward tilted blocks on the footwall of the major fault system bordering the western side of the URG. The fault in Reichenberg vicinity strikes $\mathrm{N} 020^{\circ} \mathrm{E}$. Sample X024 (Marlenheim) is located on the tilted blocks footwall, in a fracture cluster sub-parallel to the major fault striking $\mathrm{N} 035^{\circ}$ E Sample K466 from Cleebourg (Fig. 1D) is located in the footwall damage zone of a fault within the western graben shoulders major fault system. The Cleebourg fault strikes N010 ${ }^{\circ}$. Sample EPS11360 is from the EPS1 borehole, drilled in the Soultz horst (Fig. 1D). Samples A-2783,
B-2882, D-2537, E-2671, F-3225 belong to wells from the Central URG (Roemerberg, Fig. 1E). The wells are located on the nose of tilted blocks delimited to the west by a $\mathrm{N} 020^{\circ} \mathrm{E}$ striking fault. Samples analysed for $\mathrm{K}-\mathrm{Ar}$ overgrowths were selected within the same localities (Table 1, Fig. 4).

\section{Petrographic characterisation}

Standard $30 \mu \mathrm{m}$ polished thin sections and double side polished thick sections for Ar/Ar analyses were prepared for petrographic and microstructural analysis. Broad imaging of these sections was performed with a Tescan Vega3 

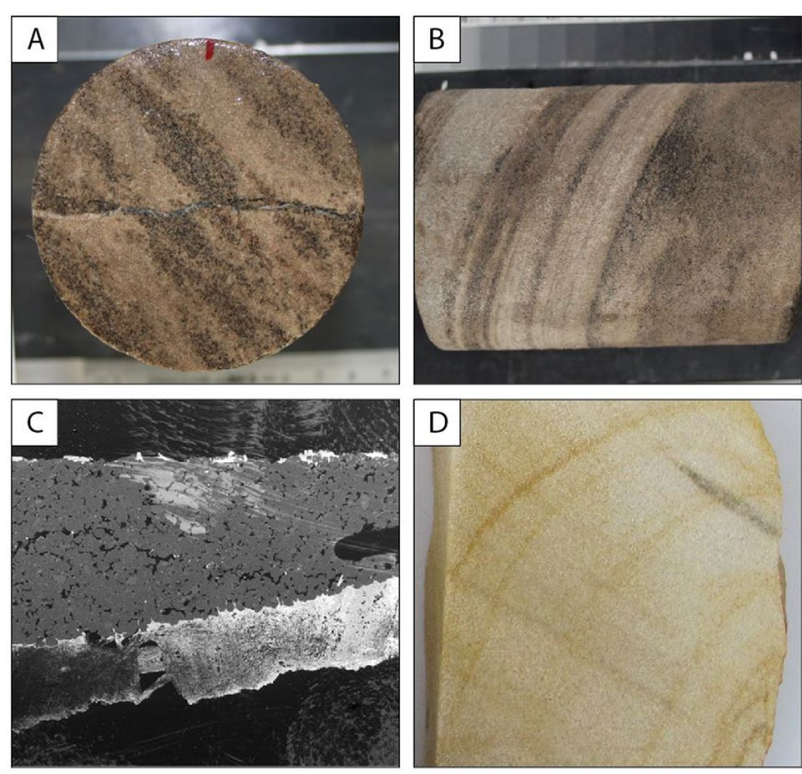

Fig. 4 Macroscopic and SEM-BSE photographs of sample categories: A D-2537: Example of fractured core-sample (category F). B B-2882: Example of non-fractured core sample (category C). C Sample X024: Example of fractured outcrop sample (category F). D Sample K500: Example of non-fractured outcrop sample (category C)

Scanning Electron Microscope (SEM). Analysis conditions were set to a beam intensity of 8-10 nA and a voltage of $15 \mathrm{kV}$. Cathodoluminescence (CL) allows easy characterisation of quartz and feldspars overgrowths generations, grain deformation, and recrystallisation. Thus, authigenic phases identification was executed through SEM imaging, backscattered electron (BSE), and cathode-luminescence (CL) observations performed on a hot cathode on Tescan VEGA3 SEM device with a current intensity of $15-17 \mathrm{nA}$ and a voltage of $15 \mathrm{kV}$.

\section{Isotope analysis}

\section{In-situ oxygen isotope analysis}

The oxygen isotopic ratios of quartz overgrowths and detrital grains were determined using a Cameca IMS 1270 ion microprobe at CRPG laboratory (Nancy, France). Analyses were acquired on a total of 634 points on 10 samples. The $\mathrm{Cs}^{+}$primary beam was settled with a spot diameter of $15-20 \mu \mathrm{m}$, an intensity of 8-10 nA, and an acceleration voltage of $10 \mathrm{kV}$. ${ }^{16} \mathrm{O}^{-}$and ${ }^{18} \mathrm{O}^{-}$secondary anions were multi-collected in two Faraday cups.

Spots were acquired following profiles in overgrowths, from the border with the detrital grain to the cement outer border, as presented in Fig. 4.
Ratios were calculated using the conventional notation presented in Eq. (1) and expressed in \% V-SMOW for both fluids and quartz overgrowths:

$\delta^{18} O_{\text {spot }}=\left(\frac{{ }^{18} \mathrm{O} /{ }^{16} O_{\text {spot }}}{{ }^{18} \mathrm{O} /{ }^{16} O_{\text {SMOW }}}-1\right) \times 1000$

The quartz CRPG internal standard was measured in between each sample, and the error on measurements was corrected with a time-dependent linear trend. The precision of measurements is $\pm 0.2 \%$.

\section{${ }^{40} \mathrm{Ar} /{ }^{39} \mathrm{Ar}$ geochronology}

Argon isotope analysis with UV laser ablation (Kelley et al. 1994) was performed at the ${ }^{40} \mathrm{Ar} /{ }^{39} \mathrm{Ar}$ geochronology laboratory of the Institute of Earth and Environmental Science, at the University of Potsdam (Germany) in 2018. Samples providing the largest feldspar overgrowths were selected from 4 locations (Cleebourg, Soultz, Roemerberg, and Marlenheim). Reichenberg samples did not exhibit sufficient thicknesses of feldspar overgrowths. Double side polished thick sections of these samples were cut into $10 * 8 * 0.8 \mathrm{~mm}$ chips. These chips were irradiated at the CLICIT facility of the Oregon State TRIGA Reactor (OSTR) at Oregon State University together with the sanidine age standard, FC3 (27.5 \pm 0.2 Ma; Uto et al. 1997), from the Fish Canyon Tuff standard from the Geological Survey of Japan, focusing on $\mathrm{K}_{2} \mathrm{SO}_{4}$ and $\mathrm{CaF}_{2}$ salts. Details on the irradiation procedure at OSTR can be found in Engelhardt et al. (2017). Ar isotope analyses by in-situ laser ablation were performed on K-feldspar detrital grains and overgrowths, with a UV pulse laser (wavelength of $266 \mathrm{~nm}$ ) of the New Wave Research DualWave laser in most cases with 20-40 $\mu$ m diameter and maximum energy of $0.3 \mathrm{~mJ}$ to ablate parts of the mineral. From 3 to 7 spots were analysed for each grain and overgrowth. The gas extracted by each ablation was then cleaned in SAES $\odot$ getters, and a cold trap cooled by ethanol to -90 ${ }^{\circ} \mathrm{C}$ by the electric cooler on the ultra-high vacuum purification line. After $10 \mathrm{~min}$ of cleaning, the gas was transferred to the noble gas mass spectrometer Micromass 5400, then was analysed for $15 \mathrm{~min}$ by a 7-cycle series of argon isotope measurements to calculate the age of analysed segments of $\mathrm{K}$-feldspar. A blank analysis was launched after analysis of a series of 3 acquisitions. Ar isotope analysis and calculation of ages and errors were conducted by MassSpec (Alan Deino Software).

\section{Basin modeling}

1D burial models were created with Petromod ${ }^{\circledR}$ 1D (Schlumberger). Burial scenarios were modelled based on the regional geological history and well data as boundary 


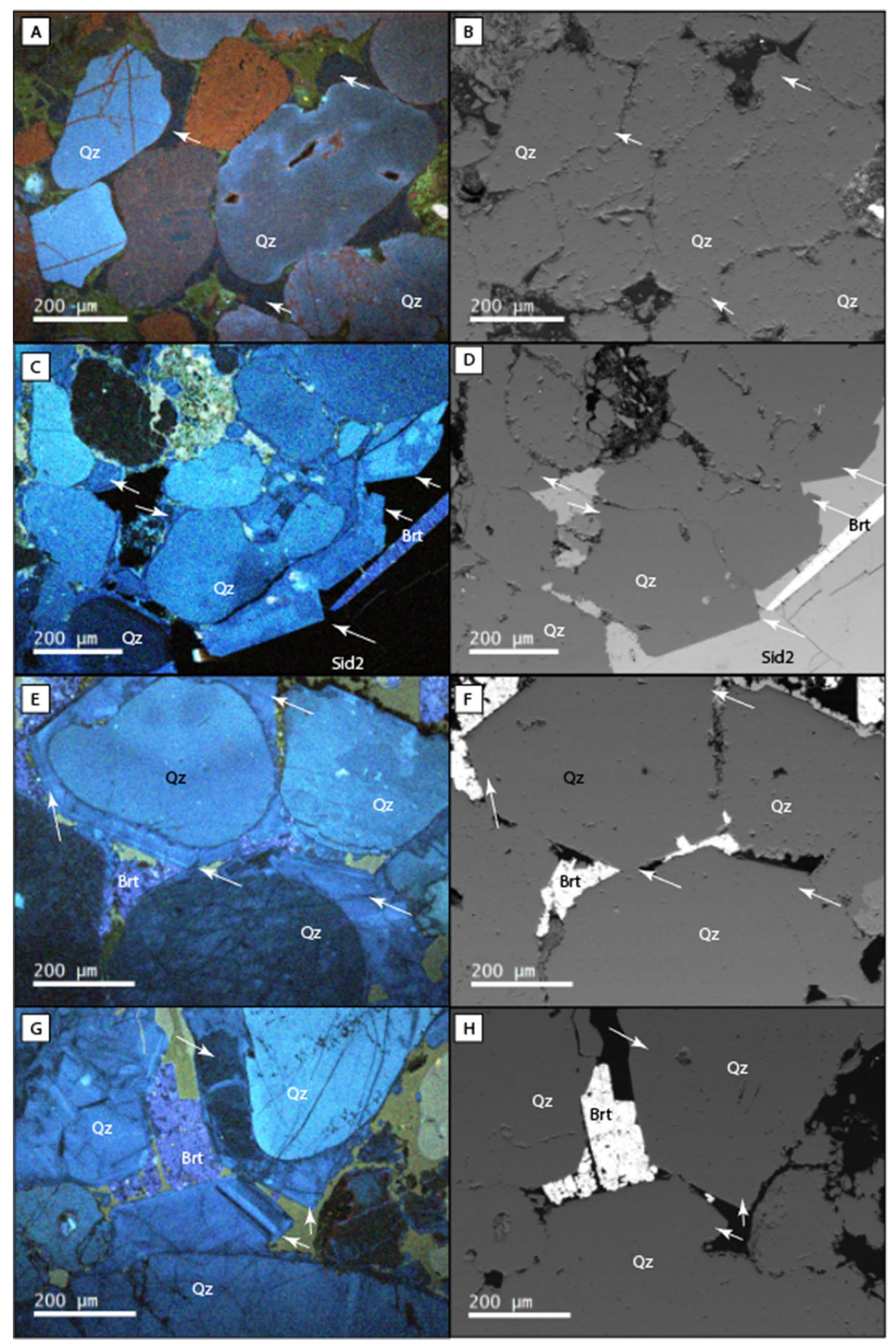


4Fig. 5 Petrographic observations of quartz overgrowths on samples. A SEM-CL microphotograph of non-luminescent quartz overgrowth (white arrow) within the intergranular space. B SEM-BSE microphotograph of (A). C SEM-CL microphotography of blue luminescent quartz overgrowth (white arrow) on the right bottom corner of the picture, euhedral quartz overgrowths developed on the fracture plane, filled by siderite and barite. Quartz cements present zonings in CL. D SEM-BSE microphotograph of (C). E SEM-CL microphotograph of zoned quartz overgrowths (white arrow) within intergranular pores, filled with barite. F SEM-BSE microphotograph of (E). G SEM-CL microphotograph of zoned quartz overgrowths (white arrow) within intergranular pores, filled with barite. Zoned overgrowths are affected by healed cracks, cross-cutting detrital, and overgrowth quartz. $\mathbf{H}$ SEM-BSE microphotograph of $(\mathbf{G})$

conditions. The modelling of the evolution of temperature with time is implemented for three locations of interest: Roemerberg and Soultz-sous-Forêts domains, representative of two localities in the central part of the basin, with a varying Tertiary burial sequence, and a third model for the shoulder domain (Burial sequence type listed on Table 1). The conditions of present thickness, erosion, deposition times, lithology, age, are available in supplementary data. Heat flow conditions are the same for the three burial scenarios (see supplementary material). The heat flow variation over time is extracted from Böcker et al. (2016), with two phases of increasing heat flow associated with hydrothermal and tectonic activity during Jurassic and Early Tertiary. The heat flow is calibrated on vitrinite reflectance from Liassic source rocks sampled within the URG and shoulders. The variations of the deposited thickness of post-Buntsandstein layers during the Mesozoic is due to differential erosion during the Late Triassic, which was more intense towards the NNW. These scenarios are tested and compared to the burial model outputs to have more insights in which periods and at which depth in correlation to the burial scenarios quartz cement may have formed.

We used the key relation between $\delta^{18} \mathrm{O}_{\text {quartz }}$ and the temperature, noted T (see Eq. (2) from Sharp et al. (2016). This equation was applied on the burial temperature curves modelled with PetroMod ${ }^{\circledR} 1 \mathrm{D}$, to estimate quartz cementation conditions from $\delta^{18} \mathrm{O}_{\text {quartz }}$ measured in overgrowths:

$\frac{4.28 \times 0.07 \times 10^{6}}{\mathrm{~T}}-\frac{3.5 \times 0.2 \times 1000}{\mathrm{~T}}=1000 \times \ln \left(\alpha_{\text {quartz }-H 20}\right)$

Three different scenarios were tested with different types of isotopic fluid compositions, e.g., $0 \%,+5 \%$, and $-5 \%$, representing different sources of fluids: formation water, diagenetic water, and meteoric water, respectively (Smith et al. 1998; Cathelineau et al. 2004; Hyodo et al. 2014; Hoefs et al. 2015; Blaise et al. 2016).

\section{Results}

\section{Petrography}

Analysed samples classify as silts and fine-grained to coarsegrained sandstones, with grain diameter ranging from 30-50 to $850-900 \mu \mathrm{m}$. Some grains and pores exhibit a clay coating composed of illitic minerals, but grain to grain contacts do not show any clay coating, suggesting an authigenic origin of this first phase of clay coating. Quartz overgrowths are present in a large amount in the intergranular spaces, mainly developed on the largest detrital grains, whose surface is not coated by smectite or illite. The thickness of quartz overgrowths ranges from 20 to $200 \mu \mathrm{m}$. In CL, the colours of detrital quartz grains vary between red, brown and dark violet. Quartz overgrowths show several zonations highlighted by varying cyan-blue intensities for samples from the category F (Fig. 5). Some laminae present welldeveloped quartz overgrowths, with almost no compaction at the bedding scale. Feldspar overgrowths show no to very soft cyan cathodoluminescence, contrasting with the bright cyan luminescence of detrital feldspar (Fig. 6). The feldspar overgrowth thicknesses range from $30 \mu \mathrm{m}$ up to a maximum of $80-100 \mu \mathrm{m}$. The intergranular pores are also partly occluded by platy illite.. This second illite texture is associated with authigenic apatite and partly covers quartz and feldspars overgrowths.

Samples originating from the vicinity of faults present a partly cemented fracture network. The fracture cementation shows (1) quartz as overgrowths on detrital quartz grains along the fracture plane; (2) intergranular siderite cement encasing euhedral faces of formerly crystallised quartz and feldspar overgrowths (Sid1) (Fig. 6 A, B); (3) blocky to needle-shaped barite cement covering both euhedral quartz overgrowths and intergranular siderite (Fig. 6A, B, C and D); and 4) siderite fracture cement encasing barite needles (Sid 2) (Figs. 5 and 6C, D). In samples from buried reservoirs, siderite and barite cementation can be pervasive in the intergranular space within the fracture plane vicinity. Only samples from currently buried sandstone present both siderite and barite within the fractures. Samples from the URG shoulders present only barite cementation, which is mostly restricted to the fracture plane.

\section{$\delta^{18} 0$ in detrital grains and quartz overgrowths}

$\delta^{18} \mathrm{O}_{\text {detrital }}$ distributions are similar for the different samples, ranging from -3.2 to $21.2 \%$, with a peak of $8-12 \%$ (Table 2, Fig. 7). 


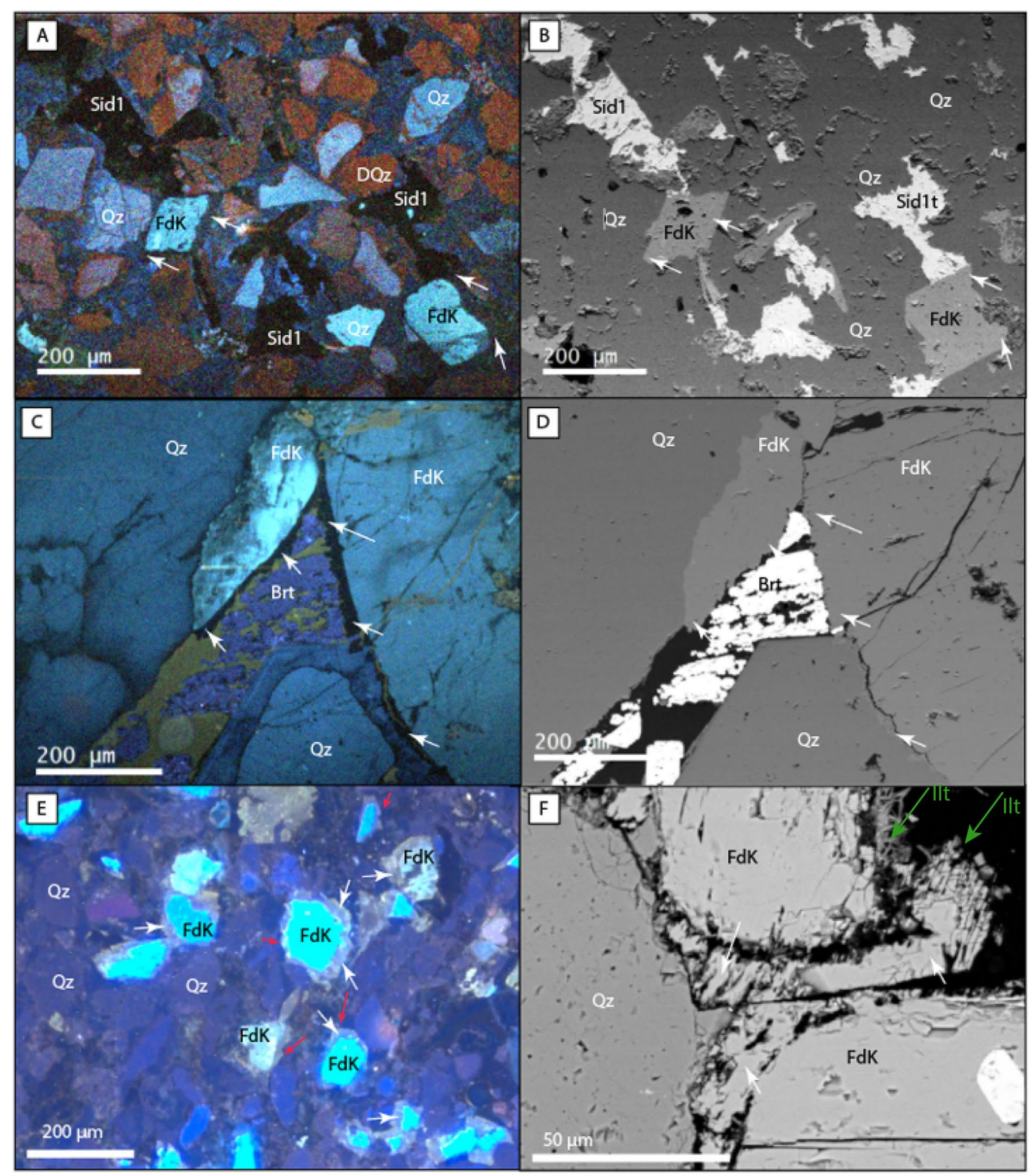

Fig. 6 Petrographic observations of feldspar overgrowths on analysed samples. A SEM-CL microphotograph of a cemented bed, with syntaxial feldspar rim (white arrow) around detrital grains. B SEM-BSE microphotograph of a cemented bed, with syntaxial feldspar rim (white arrow) around detrital grain. C SEM-CL microphotograph of feldspar syntaxial cement on the border of a detrital grain. Porosity is partly cemented by barite. Feldspar cement is encased partly by quartz overgrowth. D SEM-BSE microphotograph of feldspar

$\delta^{18} \mathrm{O}_{\text {overgrowth }}$ varies from 11 to $26.1 \%$ (Table 2, Fig. 7). Profiles of $\delta^{18} \mathrm{O}$ overgrowth were established, showing a record of the variations of $\delta^{18} \mathrm{O}$ overgrowth from the grain-cement boundary to the border of the cement rim. These profiles show two different evolutions in the $\delta^{18} \mathrm{O}$ syntaxial cement on the border of a detrital grain. Porosity is partly cemented by barite. Feldspar cement is partly encased by quartz overgrowth. E SEM-CL microphotograph of a cemented bed, with syntaxial feldspar rim (white arrow) around detrital grains, and encased by a quartz overgrowth (red arrow). F SEM-BSE microphotograph of syntaxial feldspar cement (white arrow) on the border of a detrital grain and overgrown by illite crystals (green arrow)

composition of quartz overgrowth (Figs. 8, 9). Samples of the first group (A) present a monotonous decrease of the recorded $\delta^{18} \mathrm{O}$ overgrowth from the spots closest to the detrital grain to the most recent cement (Fig. 8). The second type of pattern (samples from group B) shows chaotic variations 
Table $2 \delta^{18} \mathrm{O}_{\text {quartz }}$ average data sorted by sample and differentiating detrital and overgrowth $\delta^{18} \mathrm{O}_{\text {quartz }}$

\begin{tabular}{|c|c|c|c|c|c|c|c|c|}
\hline Sample ID & Location & Stratigraphy & Quartz type & $n$ & $\delta^{18} \mathrm{O}$ Min & $\delta^{18} \mathrm{O}$ Mean & $\delta^{18} \mathrm{O} \operatorname{Max}$ & $\sigma$ \\
\hline \multirow[t]{2}{*}{ A-2783 } & \multirow[t]{2}{*}{ Roemerberg } & \multirow[t]{2}{*}{ Upper Buntsandstein } & Detrital & 15 & 3.64 & 10.21 & 15.56 & 0.19 \\
\hline & & & Overgrowth & 4 & 18.81 & 20.19 & 23.43 & 0.19 \\
\hline \multirow[t]{2}{*}{ B-2882 } & \multirow[t]{2}{*}{ Roemerberg } & \multirow[t]{2}{*}{ Middle Buntsandstein } & Detrital & 46 & 2.75 & 10.72 & 13.41 & 0.26 \\
\hline & & & Overgrowth & 54 & 16.12 & 19.48 & 23.32 & 0.20 \\
\hline \multirow[t]{2}{*}{ D-2537 } & \multirow[t]{2}{*}{ Roemerberg } & \multirow[t]{2}{*}{ Middle Buntsandstein } & Detrital & 55 & 3.72 & 10.94 & 14.99 & 0.06 \\
\hline & & & Overgrowth & 67 & 14.11 & 19.09 & 24.64 & 0.07 \\
\hline \multirow[t]{2}{*}{ E-2671 } & \multirow[t]{2}{*}{ Roemerberg } & \multirow[t]{2}{*}{ Upper Buntsandstein } & Detrital & 3 & 9.10 & 11.45 & 13.87 & 0.26 \\
\hline & & & Overgrowth & 14 & 17.14 & 19.50 & 22.31 & 0.23 \\
\hline \multirow[t]{2}{*}{ F-3325 } & \multirow[t]{2}{*}{ Roemerberg } & \multirow[t]{2}{*}{ Middle Buntsandstein } & Detrital & 65 & 1.59 & 8.12 & 13.46 & 0.21 \\
\hline & & & Overgrowth & 44 & 10.76 & 15.79 & 19.71 & 0.19 \\
\hline \multirow[t]{2}{*}{ EPS 1360} & \multirow[t]{2}{*}{ Soultz-ss-forêts } & \multirow[t]{2}{*}{ Middle Buntsandstein } & Detrital & 84 & 1.15 & 10.77 & 16.49 & 0.16 \\
\hline & & & Overgrowth & 25 & 14.56 & 18.10 & 22.23 & 0.14 \\
\hline \multirow[t]{2}{*}{ K466 } & \multirow[t]{2}{*}{ Cleebourg } & \multirow[t]{2}{*}{ Lower Buntsandstein } & Detrital & 10 & 3.65 & 9.10 & 15.62 & 0.19 \\
\hline & & & Overgrowth & 10 & 16.73 & 20.14 & 22.88 & 0.20 \\
\hline \multirow[t]{2}{*}{ X009 } & \multirow[t]{2}{*}{ Marlenheim } & \multirow[t]{2}{*}{ Middle Buntsandstein } & Detrital & 16 & 10.25 & 12.46 & 21.23 & 0.07 \\
\hline & & & Overgrowth & 37 & 16.86 & 22.16 & 26.06 & 0.07 \\
\hline \multirow[t]{2}{*}{ X024 } & \multirow[t]{2}{*}{ Marlenheim } & \multirow[t]{2}{*}{ Middle Buntsandstein } & Detrital & 70 & -3.19 & 9.05 & 15.68 & 0.06 \\
\hline & & & Overgrowth & 49 & 12.81 & 18.99 & 23.08 & 0.06 \\
\hline \multirow[t]{2}{*}{ B002 } & \multirow[t]{2}{*}{ Reichenberg } & \multirow[t]{2}{*}{ Middle Buntsandstein } & Detrital & 4 & 9.24 & 10.90 & 12.27 & 0.06 \\
\hline & & & Overgrowth & 2 & 18.72 & 18.88 & 19.05 & 0.06 \\
\hline
\end{tabular}
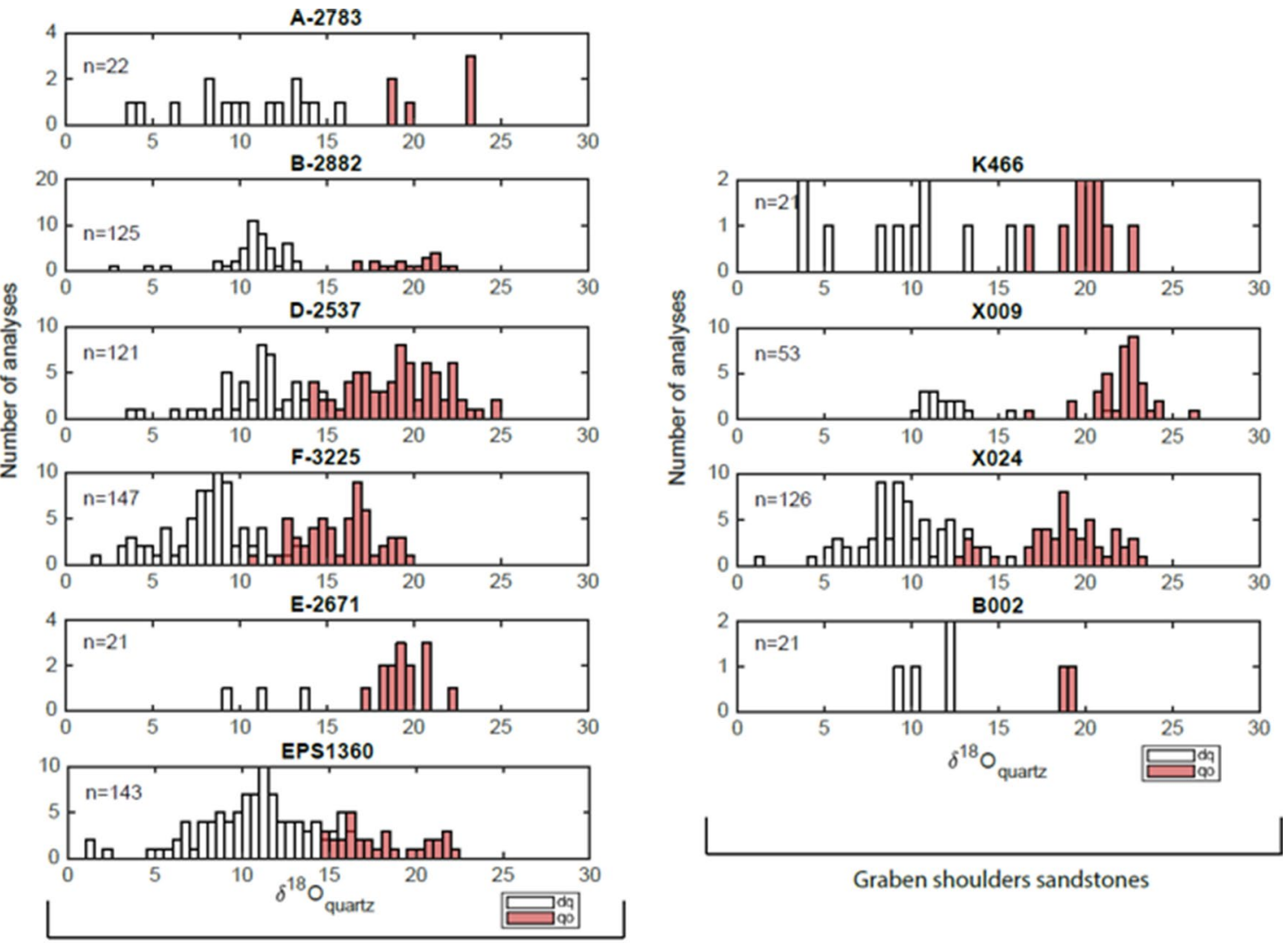

Deep-seated sandstones

Fig. 7 Histograms of $\delta^{18} \mathrm{O}_{\text {quartz }}$ values for the ten samples. Detrital grains are represented in white, and quartz overgrowth measurements in light red 

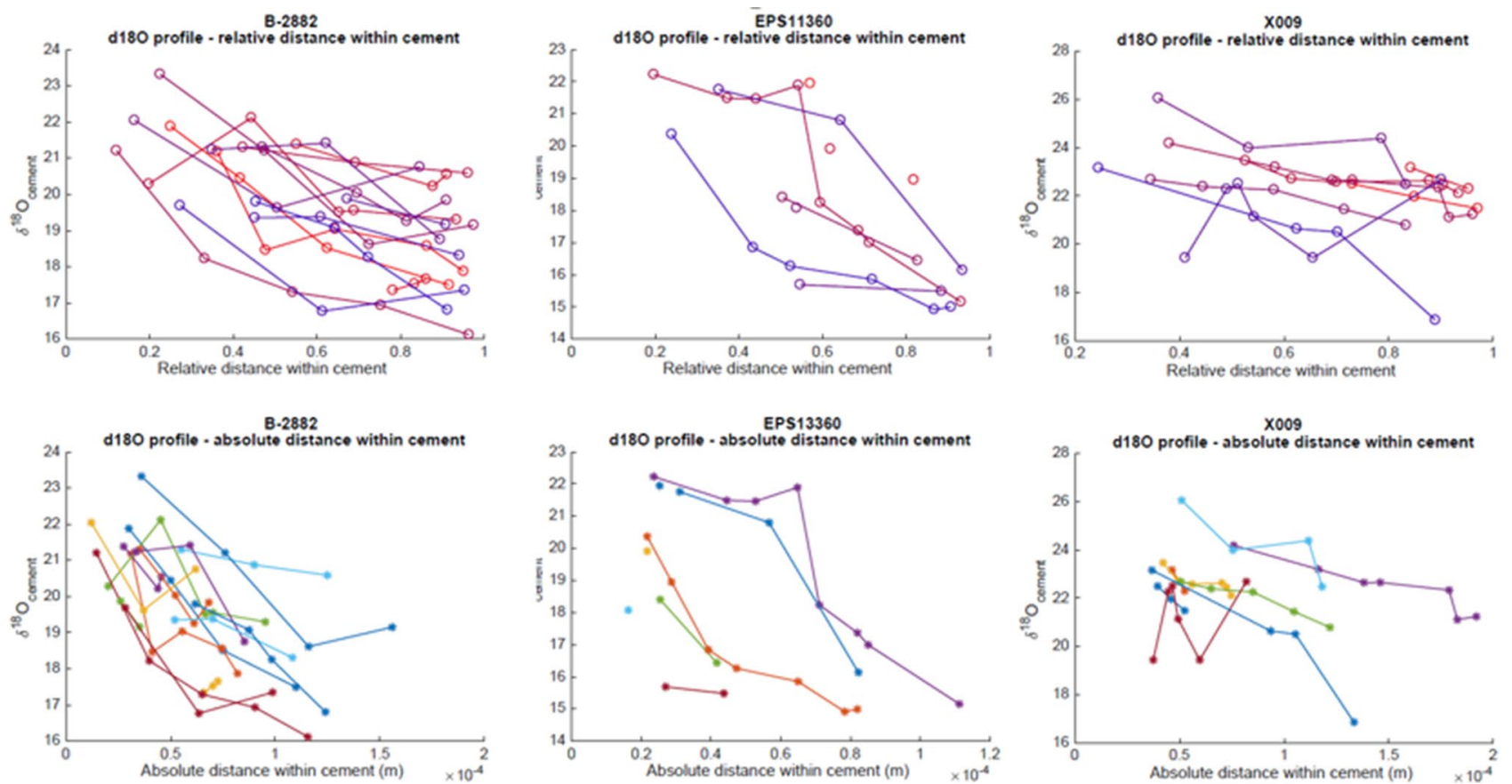

Fig. $8 \delta^{18} \mathrm{O}_{\text {quartz }}$ variations within quartz overgrowths for samples of category $\mathrm{C}$-intergranular non-disturbed behaviour
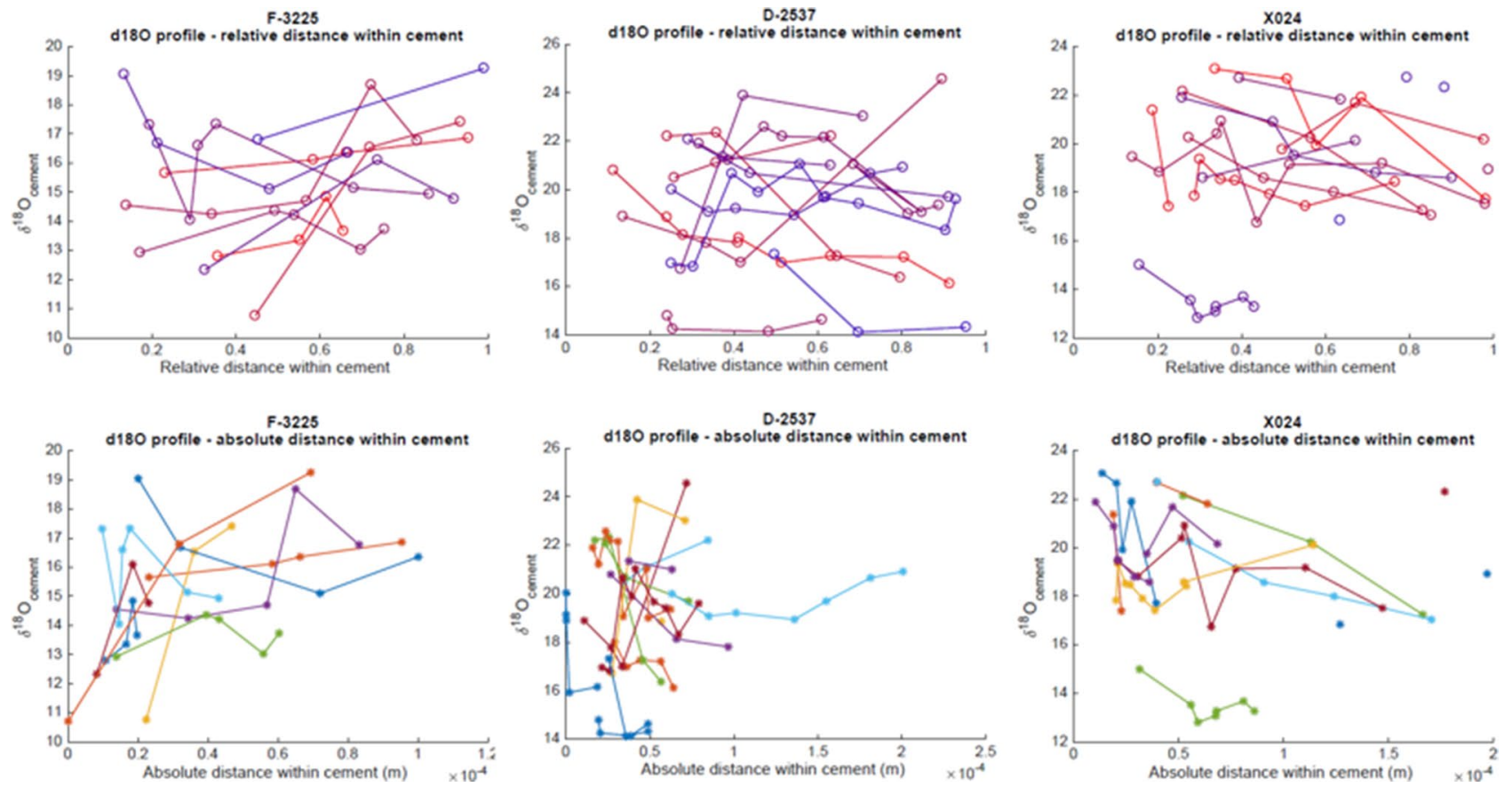

Fig. $9 \delta^{18} \mathrm{O}_{\text {quartz }}$ variations within quartz overgrowths for samples of category $\mathrm{F}$ - fracture vicinity behaviour 
in $\delta^{18} \mathrm{O}_{\text {overgrowth }}$. For example, in sample F-3225, several profiles recorded an increase in $\delta^{18} \mathrm{O}$ from the earliest to the latest overgrowths (Fig. 9).

\section{In-situ ${ }^{40} \mathrm{Ar} /{ }^{39} \mathrm{Ar}$ age of K-feldspar detrital grains and overgrowths}

The ages obtained from the K-feldspar overgrowths are distinguishable in two groups (Fig. 10): (a) a group recording an age from 250 to $230 \mathrm{Ma}( \pm 15 \mathrm{Ma})$, that corresponds to a phase of early cementation during the deposition of the sandstones, i.e., $250 \mathrm{Ma}$. (b) a second group recording a later phase of growth, from 180 to $150 \mathrm{Ma}( \pm 20 \mathrm{Ma})$.; which corresponds to mesodiagenetic cementation.

\section{Basin modelling}

The burial curves resulting from the $1 \mathrm{D}$ basin modelling (Fig. 11) are used to test several hypotheses on the $\delta^{18} \mathrm{O}_{\text {fluid }}$ from the modelled temperature curves.

From deposition (250 Ma) to the Norian (Upper Triassic), the regime of subsidence is similar for all the localities. A regional erosional phase, affecting the Upper Triassic and Middle Triassic deposits, characterises the Norian unconformity. This erosional phase and the diachronic sedimentation onset during the Jurassic explains the variability of the Mesozoic burial sequences.

A regional uplift leads to the progressive erosion of the sedimentary deposits from the Upper Cretaceous up to the Late Paleocene (Schumacher 2002; Cloetingh et al. 2006), with eroded thicknesses estimated up to $1 \mathrm{~km}$ during the Cretaceous (Böcker and Littke 2015).

With the rift opening starting during the Eocene, the burial depth varies depending on the location within the basin. Sequences on the rift shoulders (e.g., illustrated in Fig. 11A) were slightly buried during the Eocene and the Oligocene. The Cenozoic sedimentary deposits are reaching their maximum thickness of nearly $400 \mathrm{~m}$ during the Miocene. Rift shoulders undergo a second uplift, resulting in the erosion of the Cenozoic deposits and the remaining Mesozoic sequence up to the Buntsandstein Gp..

On the first blocks inside the rift, as illustrated by the case of the Soultz horst (Fig. 11B), the Cenozoic burial sequence starts during the Eocene. It continues with an increase of burial depth during the Oligocene (up to 1500-2000 m for the Buntsandstein Gp. bottom line). The Miocene uplift slightly affects the sedimentary column, with the erosion of a few tens of meters of deposits during the Tertiary.

Finally, the third configuration is illustrated by the Roemerberg case (Fig. 11C), with two majors Cenozoic subsidence phases, during the Oligocene and the Early
Miocene. The Late Miocene uplift phase leads to the erosion of approximately $100 \mathrm{~m}$ of Tertiary deposits. This third configuration is when Buntsandstein Gp. sandstones reach their maximal burial depth during the Cenozoic. For the two previous configurations, burial reaches its maximum during the pre-rift burial phase.

Following the diagenetic sequence (Fig. 12), Eq. 3 is applied to these modelling results to retrieve an age and a hypothetical $\delta^{18} \mathrm{O}_{\text {overgrowth }}$ from modelled temperature and fixed $\delta^{18} \mathrm{O}_{\text {fluid }}$ compositions (Fig. 13) to discuss the cementation timing.

The first scenario considers a fluid with a constant isotopic signature of $0 \%$.

This first scenario suggests that observed $\delta^{18} \mathrm{O}_{\text {overgrowth }}$ could form starting from $200 \mathrm{Ma}$ (Fig. 13A) from 50 to above $180^{\circ} \mathrm{C}$.

By testing the second source of a fluid with constant isotopy $=+5 \%, \delta^{18} \mathrm{O}_{\text {overgrowth }}$ could form from 90 to above $200^{\circ} \mathrm{C}$.

By testing the third source of a fluid with constant isotopy $=-5 \%, \delta^{18} \mathrm{O}_{\text {overgrowth }}$ could form from 30 to $150{ }^{\circ} \mathrm{C}$.

\section{Discussion}

The new results obtained on the isotope composition of quartz and K-feldspar allows insights into the origin of detrital grains and their overgrowth cement, potential sources for silica, fluid origin, and temperature of mineralisation. These outputs improve the understanding of the basin dynamics and fluid flow episodes in the URG.

Provenance of detrital grains.

Values of $\delta^{18} \mathrm{O}_{\text {detrital }}$ measured within the detrital quartz grains are similar for all the samples. The values of $\delta^{18} \mathrm{O}_{\text {detrital }}$ (mean: $8-10 \%$ ) for analysed samples suggest an igneous origin (Valley and Graham 1996; Götze et al. 2012; Hyodo et al. 2014). The lowest values, around 0\%, likely originate from a low- $\delta^{18} \mathrm{O}$ magma. The diversity of colours in cathodoluminescence from blue to violet shades and red may reflect multiple igneous origins, the minor amount of red grains from volcanic quartz, and a majority of blue and violet for metamorphic and plutonic quartz (Richter et al. 2003; Götze et al. 2012). The highest values of $\delta^{18} \mathrm{O}_{\text {detrital }}(16-21 \%$ ) can be linked to redeposited grains with a previous quartz overgrowth, likely from sandstones from the Grès Armoricain Fm. (Gloaguen et al. 2007; Tartèse et al. 2015). These observations are consistent with the ones presented by Soyk (2015) on samples from the Buntsandstein Gp.. The origin of detrital quartz grains of these Lower Triassic sandstones was located to the West (Köppen and Carter 2000) near the southern border of the Armorican Massif, which was eroded during the Permian and Triassic (Ballèvre 2016). 
The ${ }^{40} \mathrm{Ar} /{ }^{39} \mathrm{Ar}$ ages measured in detrital K-feldspars show a Carboniferous age for the majority of grains. These ages coincide with the Variscan orogeny, during which plutonic rocks formed in the Armorican, Vosges, Black Forest, and Rhenish massifs. Sedimentary Pre-Variscan basement, which underwent metamorphism, is associated with the oldest feldspars dating from $800 \mathrm{Ma}$. The collapse of the Variscan belt and the relief erosion is the source rock for detrital grains forming the Buntsandstein Gp. sandstones (Bourquin et al. 2006, 2009, 2011).

Argon isotopy and diagenetic paragenetic sequence.

A 4 stages paragenetic sequence is defined for the Buntsandstein Gp. sandstones, with late-stage variations depending on their structural location (Fig. 12).

(1) Formation of a detrital smectite/illite grain coating, and for some samples, the first phase of eodiagenetic K-feldspar cementation occurs in the very early stages of diagenesis (first peak of $\mathrm{Ar} / \mathrm{Ar}$ ages distribution around $250 \mathrm{Ma}$ ) (Fig. 10).

(2) Quartz overgrowths develop around detrital quartz grains and encase some of the preexisting feldspar overgrowths.

(3) The second generation of K-feldspar overgrowths, with ages ranging up to $150 \mathrm{Ma}$, develops around quartz overgrowths and detrital feldspar grains, with ages ranging up to 150 (Fig. 10).

The Ar/Ar isotopic content can distinguish the two generations of K-feldspars overgrowths. Phases (2) and (3) can be concomitant (Fig. 12).

(4) The fourth step is the precipitation of an authigenic phase of illite, which covers the euhedral quartz overgrowths. This part of the paragenetic sequence is the same for all locations sampled in this study and is similar to the previously published regional paragenetic sequence for these sandstones in the URG area (Haffen 2012; Soyk 2015; Blaise et al. 2016; Bossennec et al. 2018). Such results suggest a common burial history at the regional scale. The illitisation is accompanied by partial dissolution of K-feldspars (both detrital and overgrowths) in the analysed samples. According to previous studies, the illitisation of K-feldspar started to develop in the Buntsandstein Gp. sandstones, for the URG, approximately $180 \mathrm{Ma}$ (Liassic), lasting until approximately $150 \mathrm{Ma}$ (Late Jurassic-Early Cretaceous) (Clauer et al. 2008; Blaise 2012). The youngest ages recorded in $\mathrm{K}$-feldspar overgrowths are contemporaneous with the last steps of illitisation. During the Late Jurassic, several hydrothermal events are also recorded in the area, leading to hot fluid flow and extensive precipitation of authigenic illite around fault zones, recorded in various formations of the Mesozoic sedimentary deposits, in the area of the future URG (Meyer et al. 2000; Brockamp and Clauer 2005; Cathelineau et al. 2012; Blaise et al. 2016). This generation of authigenic illite, present in the damage zones of faults; is recognised in several localities around the URG, suggesting a regional fault activation. Because K-feldspars analysed are partly dissolved, and due to the relatively smaller size and thickness of the analysed overgrowths around the detrital grains, these conditions did not allow us to perform measurements with higher precision than $\pm 15 \mathrm{Ma}$. Indeed, the errors of ${ }^{40} \mathrm{Ar} /{ }^{39} \mathrm{Ar}$ ages on the K-feldspar increased when the spots' size was smaller. As the laser spot size is decreased, less material is evaporated, reducing the overall signal amplitude. However, the interpreted ages give a first order of the timing at which K-feldspar cements crystallised. Two Ar/Ar age peaks are determined, suggesting two generations of K-feldspar overgrowths, which fit within
Fig. $10 \quad \mathrm{~A}^{40} \mathrm{Ar} /{ }^{39} \mathrm{Ar}$ ages of $\mathrm{K}$-feldspar in samples, distinguishing detrital K-feldspars (grey) and K-feldspar overgrowths (purple). B Details on overgrowths
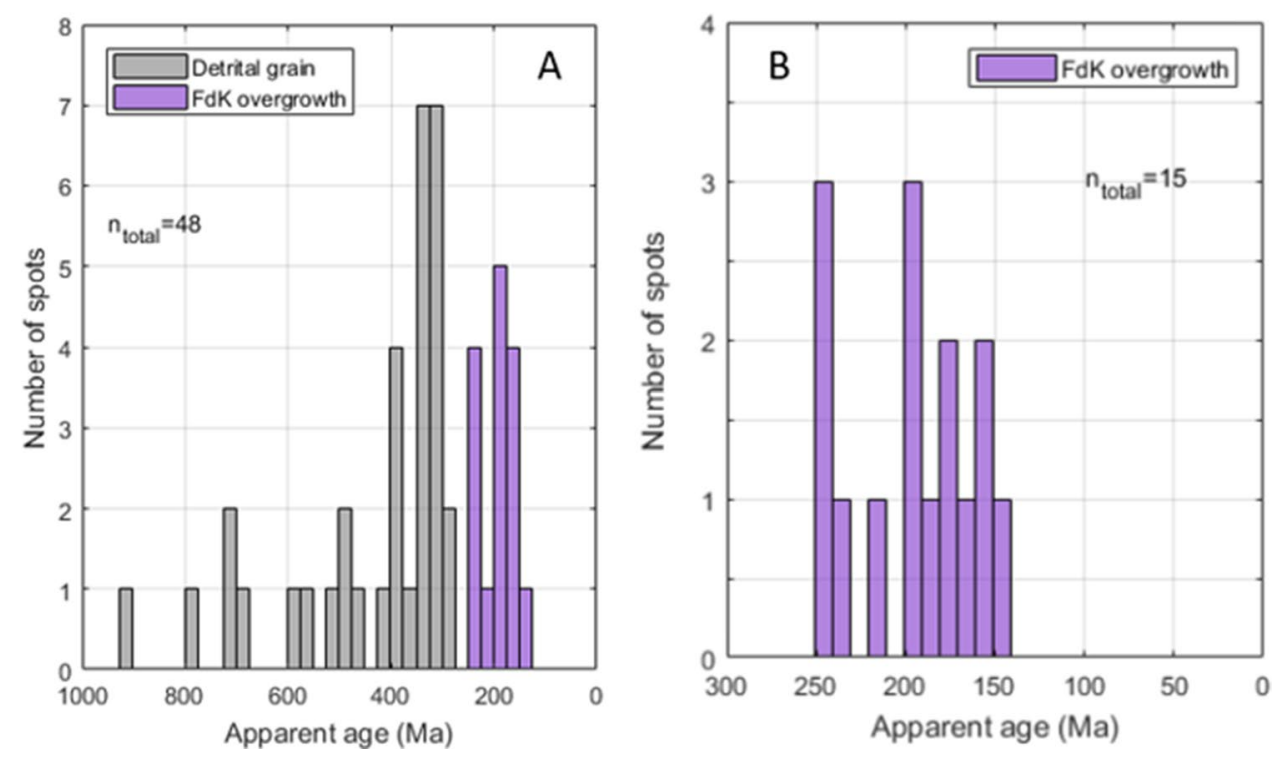

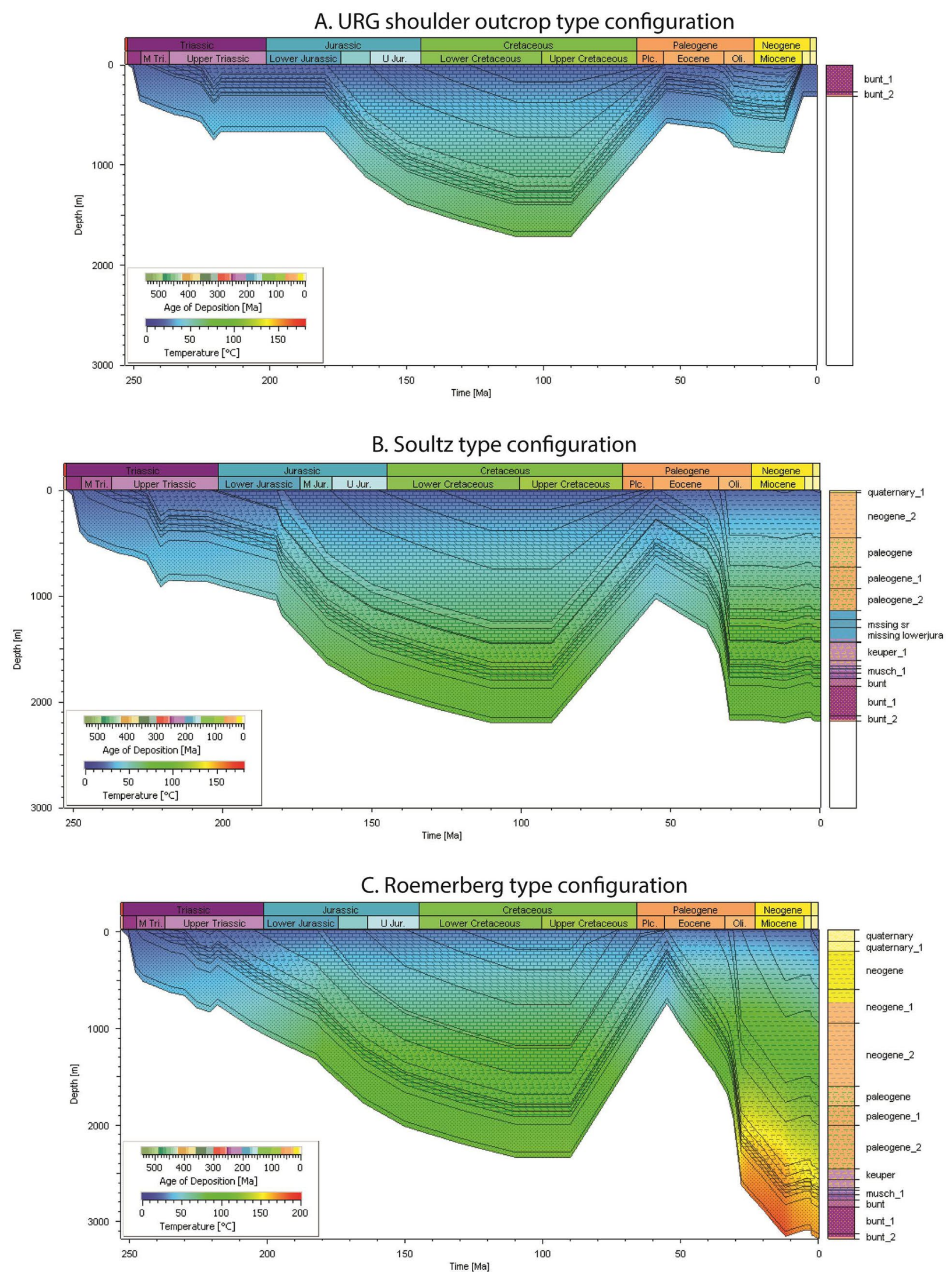

Fig. 11 1D burial curves for the three scenarios modelled: A URG shoulder outcrop configuration. B Soultz type configuration with moderate burial during Oligocene. C Roemerberg type configuration with deep-seated reservoirs due to tertiary burial sequence 


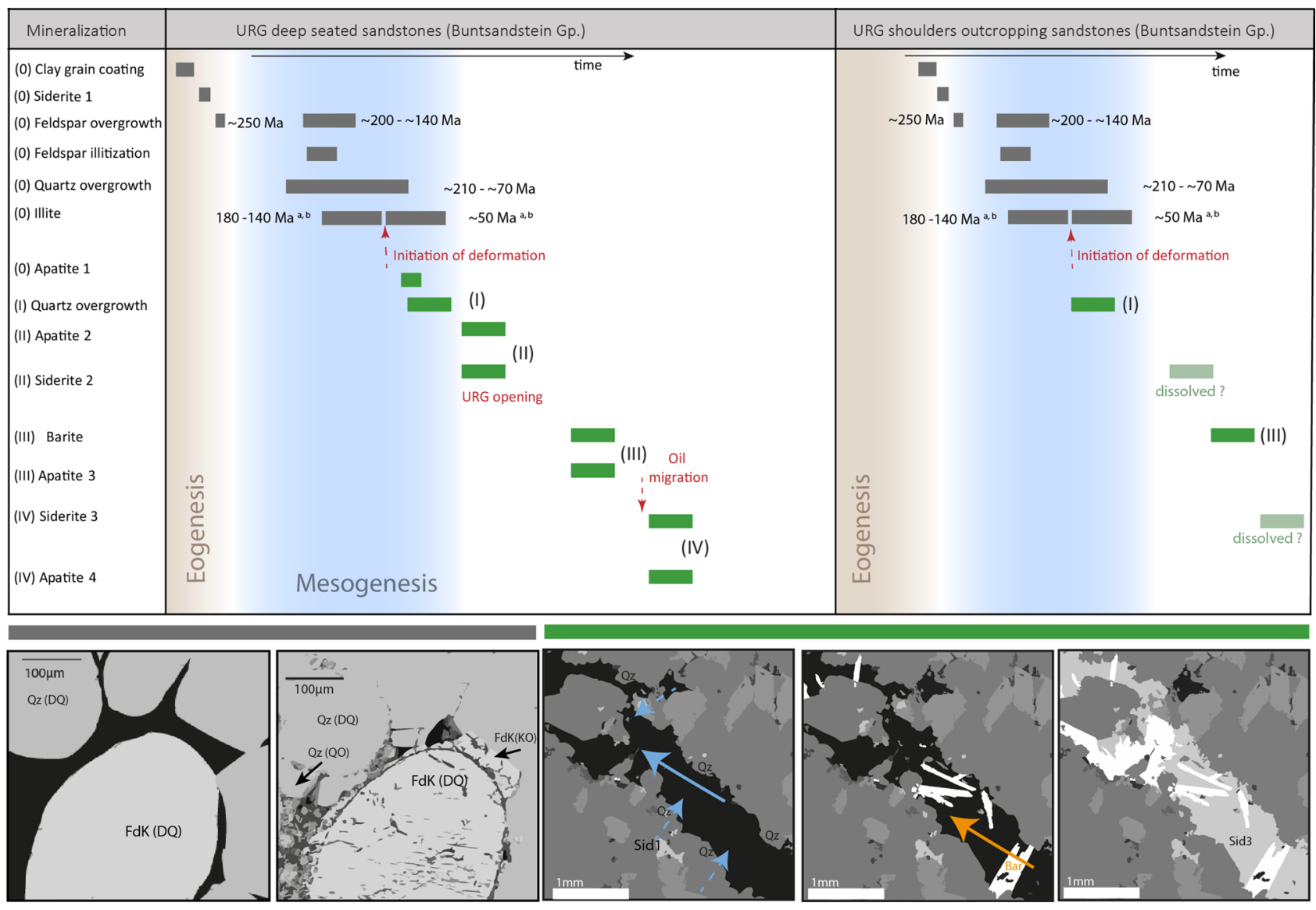

Fig. 12 Paragenetic sequence within the Buntsandstein Gp. sandstones. Two paragenetic sequences are established, one for deepseated sandstones and one for sandstones from outcrops. In grey, the diagenetic sequence affecting the sandstone before the deformation; in dark green, events affecting the fracture network and surrounding intergranular space; in light green, potentially dissolved siderite phases. Reference for dating a (Blaise et al. 2016), b (Schleicher et al. 2006)

However, as no biogenic silica is observed, silica sources restrain to classical diagenetic reactions products. Some of the quartz overgrowths in the observed samples show bright blue and dark violet zonations under hot CL. These bright blue CL emissions are induced by $\mathrm{Al}^{3+}$, which substitutes $\mathrm{Si}^{4+}$ (Boggs and Krinsley, 2006; Götte et al. 2013; Götze et al. 2012). Two primary sources could be suspected as aluminium is a product of the albitisation of K-feldspars (Mark et al. 2005; Lander and Bonnell 2010; Xi et al. 2015). Albitisation also releases silica (Brosse et al. 2000; Mansurbeg et al. 2008; Xi et al. 2015). K-feldspar is poorly albitised in studied samples. Illitisation of detrital K-feldspars could be the second source for Al (Lanson et al. 2002; Lander and Bonnell 2010; Götte et al. 2013). K-feldspar grains show very scarce illitisation, restricted to detrital grain boundary and transgranular cracks surface. However, most of the felspar grains remain unaltered, except in deep-seated reservoirs in Roemerberg within the vicinity of fault systems. According to the observations of relatively well-preserved feldspars, except within fault zones, it is likely that pore 

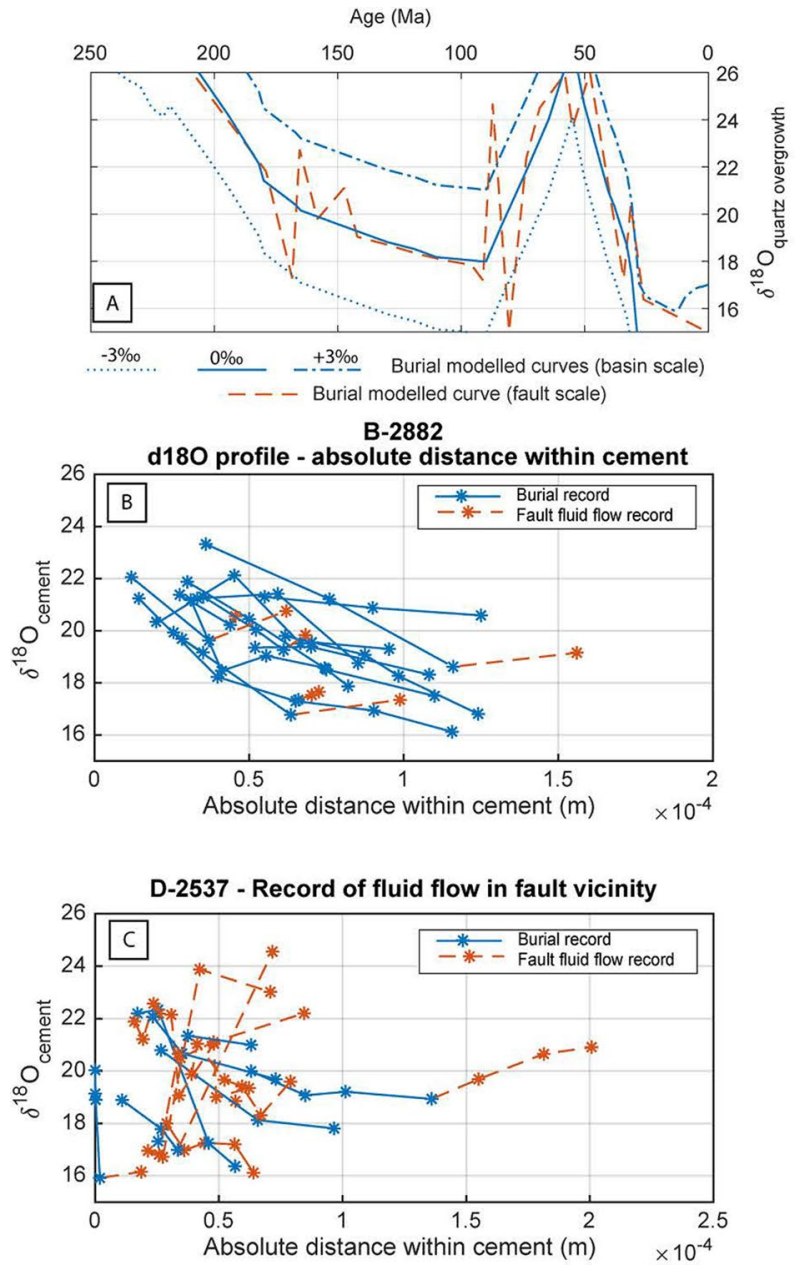

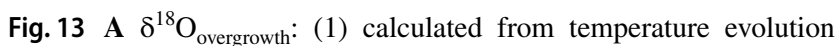
during simple basin burial (blue line) and (2) calculated from temperature evolution during burial coupled to fault fluid-flow within sandstones (orange dashed line). B Profiles in a sample recording mainly burial evolution. C Profiles in a sample recording mainly the

water remains saturated in $\mathrm{K}^{+}, \mathrm{SiO}_{2}$, and $\mathrm{Al}$, which also allows the growth of K-feldspars overgrowths (Lanson et al. 2002). Fluids enriched in $\mathrm{Al}, \mathrm{K}^{+}$, and $\mathrm{SiO}_{2}$, if sourced from $\mathrm{K}$-feldspar transformation, should then have an external origin (Yuan et al. 2015) and could be drained to the sandstones more efficiently within the fault damage zone, as shown in a previous study (Bossennec et al. 2018). From damage zones, fluids may percolate through the porous sand bodies, from volumes, where albitisation took place, i.e., fault zones within the crystalline basement (Brockamp et al. 2003; Brockamp and Clauer 2005; Schmidt et al. 2017). The illitisation of clay mineral grain coatings may also provide an internal silica source (Yang 2000; Tournier 2010; Zhu et al. 2015). The illitisation of smectites, for example, can affect the isotopic composition of the pore fluid by increasing

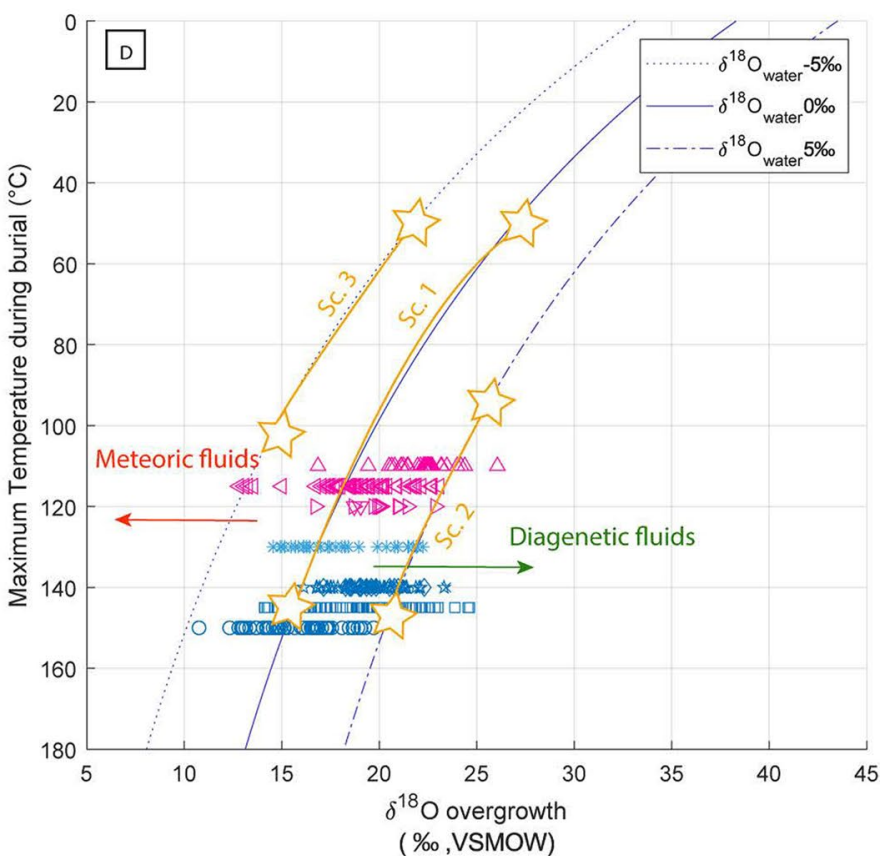

fluid flow. D Diagram of the evolution of $\delta^{18} \mathrm{O}$ overgrowth versus the temperature for three modelled $\delta^{18} \mathrm{O}$ fluid values (- 5\% meteoric, $0 \%$ initial formation water, $+5 \%$ diagenetic), and associated ranges encountered in samples

$\delta^{18} \mathrm{O}_{\text {fluid }}$ from +2 to $+5 \%$ (Tournier et al. 2010; Pollington et al. 2011; Hyodo et al. 2014).

Chemical compaction is another potential internal source of silica and is well marked in fine grain-sized laminae of Buntsandstein Gp. sandstones (Haffen et al. 2015; Soyk 2015; Schmidt et al. 2020). The pore fluid mediates the effect of compaction on the value of $\delta^{18} \mathrm{O}_{\text {fluid }} \cdot \mathrm{SiO}_{2}$ dissolves in the water, and the isotope composition is re-equilibrated. When $\mathrm{SiO}_{2}$ precipitates, the $\delta^{18} \mathrm{O}$ composition is then a function of $\delta^{18} \mathrm{O}_{\text {fluid }}$ and temperature.

Massive illitisation in claystones and shales from different sedimentary formations or feldspar illitisation in the crystalline basement releases silica into the circulating brine. The migration from this external brine into the sandstone reservoir is enhanced by fault activity, usually allowing fluid migration within the fault damage zones. 
No clear distinction can be deciphered regarding the silica source. Likely candidates are feldspar dissolution (partial in areas weakly affected by fault systems), feldspar illitisation, increased in the vicinity of a fault zone, chemical compaction of detrital quartz grains, and clay mineral recrystallisations, which can commonly be observed in sandstone diagenesis (Worden and Morad 2000; Wilkinson 2001; Worden and Burley 2003; Tournier et al. 2010).

\section{Fluid typing and temperature of mineralisation}

Although the burial sequences are different during the Cenozoic for sandstones located on the graben shoulders and in the centre of the basin, the range of recorded $\delta^{18} \mathrm{O}$ in the quartz overgrowth is similar for the entire data set, with the highest values registered at $26 \%$ and lowest values of $12 \%$. This homogeneous range is an argument for the initiation of quartz cementation during the Late Triassic and Jurassic. These profiles can result from two settings of quartz cementation conditions:

A monotonous decrease of $\delta^{18} \mathrm{O}_{\text {overgrowth }}$ from the contact with the detrital grain to the cement border characterise the first regime of quartz cementation (Figs. 8, 13). Even if none of the overgrowths analysed show the record of a complete burial sequence, the assemblage of the several profiles for each sample is covering the interval of $\delta^{18} \mathrm{O}$ on quartz, which can be related to a continuous burial phase and quartz precipitation during the Mesozoic (Harwood et al. 2013). Values of profiles in this regime range from 26 to $16 \%$.

The second quartz cementation regime is observed on samples collected in the damage zones of faults (Figs. 9, 13) and on overgrowths that present bright blue zonings in $\mathrm{CL}$ analyses. For these samples, the analysed profiles present a chaotic pattern of $\delta^{18} \mathrm{O}$ variation within the quartz overgrowth. The values of $\delta^{18} \mathrm{O}$ are lower than those for the previous regime. Here, $\delta^{18} \mathrm{O}$ ranges from $19 \%$ to $12 \%$. Overall, samples from category $F$ have lower values of $\delta^{18} \mathrm{O}$ registered in quartz overgrowths. The fluctuations observed in this second type of profile could be connected either to very local temperature variations or variations of the fluid types due to fault activity and fluid transfer within faults, disturbing the geochemical conditions locally.

One means of estimating the minimum mineralisation temperatures and the nature of the fluids is micro-thermometry. Unfortunately, the overgrowths analysed in this study, even from thick sections, do not have inclusions large enough to be analysed (micron to submicron size). Previous studies on fluid inclusions in quartz overgrowths provide insights into fluid type and source variations within the basin and at the basin-basement interface (Dubois et al. 1996; Smith et al. 1998; Boiron et al. 2011; Gardien et al. 2016).

The oxygen isotopic signature aids the identification of the fluid origin. Three sources of fluid are differentiated.
Generally, positive $\delta^{18} \mathrm{O}_{\text {fluid }}$ from +2 to $+5 \%$ is associated with the release of waters during the illitisation of clays (Cathelineau et al. 2004; Hyodo et al. 2014; Blaise et al. 2016). Hot meteoric fluids involved in hydrothermal mineralisation in the area also have a peculiar signature, with a negative $\delta^{18} \mathrm{O}_{\text {fluid }}$, ranging from - 10 to $-5 \%$ (Zwingmann et al. 1999; Hoefs et al. 2015). Currently, formation waters sampled within the Buntsandstein Gp. sandstones have a $\delta^{18} \mathrm{O}_{\text {fluid }}$ ranging from -1.1 to $-2.9 \%$ (Sanjuan et al. 2016). The range of $\delta^{18} \mathrm{O}$ overgrowth is not only explained by pure temperature variations with time. It is, therefore, necessary to test different scenarios (Fig. 13).

The first scenario considers a fluid with a constant isotopic signature of $0 \%$, reflecting a fluid similar to Buntsandstein $\mathrm{Gp}$. formations waters at the time of deposition. For this value, quartz cementation starts at $50{ }^{\circ} \mathrm{C}$ for the first profiles. It continues monotonically up to temperatures of $130-140{ }^{\circ} \mathrm{C}$ for samples outside of damage zones (Fig. 13), following the burial models (Fig. 11). This fluid hypothesis fits the majority of the measured values, other fluid sources or higher temperature could explain the lower values of $\delta^{18} \mathrm{O}$ overgrowth. The record of the monotonous burial of the Buntsandstein Gp. sandstones corresponds to previous results, using other burial markers, as vitrinite reflectance (Blaise et al. 2014, 2016; Böcker et al. 2016).

The second scenario tests a fluid with constant isotopy $=+5 \%$, which represents a diagenetic origin. The calculated temperatures show a start of quartz cementation at $90{ }^{\circ} \mathrm{C}$ and up to more than $250{ }^{\circ} \mathrm{C}$. The start of cementation at $90{ }^{\circ} \mathrm{C}$ is plausible due to the improved kinetics of quartz cementation at temperatures above $80{ }^{\circ} \mathrm{C}$ (Bjørlykke et al. 2004). However, the temperatures calculated for the terminal part of the profiles $\left(>180^{\circ} \mathrm{C}\right)$ are inconsistent with the geological history. This source explains the smallest number of measurements for the expected burial conditions, and other fluid sources and crystallisation temperatures must be expected.

By testing the third source of a fluid with constant isotopy $=-5 \%$, the temperatures obtained by calculation are not ideal for the monotonically decreasing profiles (beginning at $50{ }^{\circ} \mathrm{C}$ and rising up to $120^{\circ} \mathrm{C}$ ). However, they explain the decreases and fluctuations recorded by the samples exhibiting chaotic profiles near the faults.

The combination of these three scenarios allows defining a frame for fluid isotopic signatures and their evolution. Overall, for the first overgrowths with values above $20 \%$ (the closest to the grain boundaries), the main domain for fluid typing is comprised between 0 and slightly negative $\delta^{18} \mathrm{O}_{\text {fluid }}$ (Fig. 13D). Fluid inclusion studies (Soyk, 2015) associate these first overgrowths with a homogenisation temperature $\left(\mathrm{T}_{\mathrm{h}}\right)$ of $50{ }^{\circ} \mathrm{C}$, concordant with a fluid composition around $0 \%$, and mineralisation linked to a meteoric or a sedimentary fluid. $\mathrm{Tm}_{\text {ice }}$ ranges vary, suggesting 
two possible origins, e.g., meteoric for low salinity fluids $\left(\mathrm{Tm}_{\text {ice }}\right.$ above $\left.-5^{\circ} \mathrm{C}\right)$ and more saline brines from sedimentary fluids. The salinity can also vary in a single cementation phase due to heterogeneous trapping (Cathelineau and Boiron 2010).

Following the onset of quartz cementation, with the first decrease of $\delta^{18} \mathrm{O}$, the next-coming increase of $\delta^{18} \mathrm{O}$ registered in sample profiles can thus be associated to a) a decrease of temperature, with uplift, while there is no hot fluid flow, the temperature returns to the global burial temperature at this depth or b) fluid flow with a $\delta^{18} \mathrm{O}_{\text {fluid }}$ isotopic signature above $0 \%$. Fluids containing solutes from illitisation reactions are fluids that can match this scenario, as their isotopic $\delta^{18} \mathrm{O}_{\text {fluid }}$ is usually higher than $2 \%$. This variability of the isotopic composition of fluids is associated with fluid-mixing processes, as underlined by salinity variations in quartz mineralisations in fault zones, such as in the Soultz granite (Dubois et al. 1996; Smith et al. 1998; Cathelineau and Boiron 2010) or in the Schwarzwald (Staude et al. 2009; Pfaff et al. 2010).

A combination of a) and b) is also possible, as sedimentary brines from overlying layers might also be cooler.

The intermediate and most numerous values of $\delta^{18} \mathrm{O}$ overgrowths (between 15 and $20 \%$ ) are associated with higher $\delta^{18} \mathrm{O}_{\text {fluid }}$. This increase of $\delta^{18} \mathrm{O}$ fluid is related to the high $\delta^{18} \mathrm{O}$ fluid released by illitisation. This illitisation of smectitic clay grain coatings is enhanced in the fault vicinity, as suggested by the chaotic profiles.

The next generations of fluid inclusions analysed in quartz overgrowths by Soyk (2015) show $\mathrm{T}_{\mathrm{h}}$ around $150{ }^{\circ} \mathrm{C}$. These FI are characterised by low salinity $\left(\mathrm{T}_{\mathrm{m}}\right.$ ice above $\left.-5^{\circ} \mathrm{C}\right)$, which could mark the higher contribution of meteoric fluids infiltrated in the deep basement on quartz cementation in the Buntsandstein Gp sandstones. This second phase of quartz cementation is recorded regionally (Smith et al. 1998; Dubois et al. 2000; Cathelineau and Boiron 2010). The fluid should have a $\delta^{18} \mathrm{O}_{\text {fluid }}$ ranging from 0 to $-5 \%$ to reach the obtained values of the latest $\delta^{18} \mathrm{O}$ overgrowths (below 15\%) at $150{ }^{\circ} \mathrm{C}$. This estimated value for $\delta^{18} \mathrm{O}_{\text {fluid }}$ is typical for present-day meteoric fluids. Hot meteoric fluids related to fault activity are good candidates because of their isotopic $\delta^{18} \mathrm{O}_{\text {fluid }}$ between -10 and $-5 \%$, their low salinity, and the high temperature of the fluid $\left(>180^{\circ} \mathrm{C}\right.$ ) (Schwinn et al. 2006; Baatartsogt et al. 2007; Pfaff et al. 2010; Boiron et al. 2011; Brigaud et al. 2020).

\section{Conclusions}

In situ analysis of oxygen isotopic ratios provides an analytical tool to decipher the sources of detrital and authigenic quartz. The average $\delta^{18} \mathrm{O}_{\text {quartz }}$ compositions of detrital grains suggest a predominantly igneous origin. Quartz overgrowths present two categories of profiles. The first category of profile records the monotonous decrease of $\delta^{18} \mathrm{O}_{\text {overgrowth }}$, and is related to the Mesozoic burial sequence. The second category of profile has a more chaotic pattern. This profile shape is explained by the variations of the temperature range, eventually locally associated with a variation of the fluid isotopic composition in the vicinity of faults.

The proposed burial and paragenetic sequence can be summarised in two phases and associated geological processes:

1) The first phase of cementation occurs during a monotonous burial, from $\sim 180 \mathrm{Ma}$ up to $\sim 150-140 \mathrm{Ma}$.

2) The second phase of quartz cementation is linked to the first episodes of deformation and fluid flow starting from the Early Jurassic and associated with the hot fluid pulses responsible for regional illitisation. The record of $\delta^{18} \mathrm{O}_{\text {overgrowth }}$ is chaotic due to the interaction between several types of external fluid sources, with a mix of hot hydrothermal fluids and co-generated ${ }^{18} \mathrm{O}$-enriched illitisation fluids, which would explain the widespread strong zonation observed in quartz overgrowths associated with these chaotic profiles.

These signal disturbances recorded in the overgrowths are likely to be posterior to the regional burial phase recorded by the first type of profile. Before the Cenozoic rift opening, quartz overgrowths form prior to authigenic illite dated from the Late Jurassic to Paleogene. This modelling also correlates with the absolute in-situ ${ }^{40} \mathrm{Ar} /{ }^{39} \mathrm{Ar}$ dating results obtained on the feldspar overgrowths, with the youngest ages corresponding to $140 \mathrm{Ma}$, i.e., in the late Jurassic period.

This study indicates that most of the intergranular pore network cementation ceases before the deformation associated with the rifting phase during the Eocene. The first phases of deformation impact the latest phases of quartz cementation, as recorded in the disturbance of the isotopic signature of quartz overgrowth in the vicinity of fractures.

Based on the analysis of $\delta^{18} \mathrm{O}$ on quartz overgrowths, the diagenetic history recorded is very similar for the entire study area, with the same ranges of values recorded on the graben shoulders and the buried parts of the basin. This study shows the importance of understanding the fault system activity during the reservoir geological evolution. Here, the pore network modification due to cementation mostly predates the basin structuration in blocks. Similar intergranular pore network diagenesis could be expected for reservoir blocks unaffected by faults, not depending on the current burial position.

Supplementary Information The online version contains supplementary material available at https://doi.org/10.1007/s00531-021-02080-2.

Acknowledgements This work was supported by a $\mathrm{Ph} . \mathrm{D}$. grant from ENGIE, Neptune Energy, and the University of Lorraine. We would like to thank especially the geoscience team from ENGIE Deutschland 
GmbH (now Neptune Energy Germany) and their partner Palatina GeoCon GmbH \& Co. KG., for the supply of core material, their scientific support, and rich debates. We also thank the Rauscher Company for access to the Cleebourg quarry and sampling authorisations. All the GeoRessources laboratory and Neptune Energy and ENGIE collaborators are thanked for numerous advice, settings, supplies, and measurements. We would like to thank the Institute of Earth and Environmental Science in Potsdam for the Ar/Ar isotope facility and advice. The quartz overgrowths analysis could not have been performed without the help and experience of the collaborators from the CRPG laboratory (Nancy). We would like to thank the ChronoEnvironnement laboratory in Besançon for cold cathode facility supply and discussions on sandstones diagenesis. We also thank Schlumberger for providing the Petromod academic license. We are grateful to the editor and the reviewers for their time and suggestions for improving the manuscript.

Authors' contributions $\mathrm{CB}, \mathrm{YG}, \mathrm{JB}, \mathrm{BK}, \mathrm{LM}$, and IM contributed to the study conception and design. CB, JB, MS, and J-PS performed the material preparation, data collection and analysis. BK, YG, LM, and IM helped interpret the data. CB wrote the first draft of the manuscript and all authors commented on previous versions of the manuscript. All authors read and approved the final manuscript.

Funding Open Access funding enabled and organized by Projekt DEAL. Ph.D. Grant from ENGIE, Neptune Energy, and the University of Lorraine.

Availability of data and materials Attached Excel file.

\section{Declarations}

Conflict of interest All authors declare that they have no conflict of interest.

Open Access This article is licensed under a Creative Commons Attribution 4.0 International License, which permits use, sharing, adaptation, distribution and reproduction in any medium or format, as long as you give appropriate credit to the original author(s) and the source, provide a link to the Creative Commons licence, and indicate if changes were made. The images or other third party material in this article are included in the article's Creative Commons licence, unless indicated otherwise in a credit line to the material. If material is not included in the article's Creative Commons licence and your intended use is not permitted by statutory regulation or exceeds the permitted use, you will need to obtain permission directly from the copyright holder. To view a copy of this licence, visit http://creativecommons.org/licenses/by/4.0/.

\section{References}

Aretz A, Bär K, Götz AE, Sass I (2015) Facies and diagenesis of permocarboniferous geothermal reservoir formations (upper Rhine Graben, SW Germany): impact on thermophysical and hydraulic properties. World Geotherm Congr 2015:11

Baatartsogt B, Schwinn G, Wagner T et al (2007) Contrasting paleofluid systems in the continental basement: A fluid inclusion and stable isotope study of hydrothermal vein mineralization, Schwarzwald district, Germany. Geofluids 7:123-147. https:// doi.org/10.1111/j.1468-8123.2007.00169.x

Ballèvre M (2016) Le Massif armoricain après l'orogenèse varisque : Une ligne de partage des eaux au trias. Géochronique $140: 47-48$
Berger JP, Reichenbacher B, Becker D et al (2005) Eocene-Pliocene time scale and stratigraphy of the Upper Rhine Graben (URG) and the Swiss Molasse Basin (SMB). Int J Earth Sci 94:711-731. https://doi.org/10.1007/s00531-005-0479-y

Bergerat F (1987) Stress fields in the European platform at the time of Africa-Eurasia collision. Tectonics 6:99-132

Bjørkum P, Oelkers E, Nadeau PH et al (1998) Porosity prediction in quartzose sandstones as a function of time, temperature, depth, stylolite frequency, and hydrocarbon saturation. Am Assoc Pet Geol Bull 82:637-648. https://doi.org/10.1306/1D9BC5CF172D-11D7-8645000102C1865D

Bjørlykke K (2014) Relationships between depositional environments, burial history and rock properties. Some principal aspects of diagenetic process in sedimentary basins. Sediment Geol 301:1-14. https://doi.org/10.1016/j.sedgeo.2013.12.002

Bjørlykke K, Egeberg PK (1993) Quartz cementation in sedimentary basins. Am Assoc Pet Geol Bull 77:1538-1548. https://doi.org/ 10.1306/BDFF8EE8-1718-11D7-8645000102C1865D

Bjørlykke K, Chuhan F, Kjeldstad A et al (2004) Modelling of sediment compaction during burial in sedimentary basins. Elsevier Geo Eng B 2:699-708. https://doi.org/10.1016/S1571-9960(04)80121-6

Blaise T, Barbarand J, Kars M et al (2014) Reconstruction of low temperature $\left(<100^{\circ} \mathrm{C}\right)$ burial in sedimentary basins: a comparison of geothermometer in the intracontinental Paris Basin. Mar Pet Geol. https://doi.org/10.1016/j.marpetgeo.2013.08.019

Blaise T, Clauer N, Cathelineau M et al (2016) Reconstructing fluidflow events in Lower-Triassic sandstones of the eastern Paris Basin by elemental tracing and isotopic dating of nanometric illite crystals. Geochim Cosmochim Acta 176:157-184. https:// doi.org/10.1016/j.gca.2015.12.018

Blaise T (2012) Histoire thermique et interactions fluides-roches dans l'Est du Bassin de Paris. Université de Lorraine

Böcker J, Littke R (2015) Thermal maturity and petroleum kitchen areas of Liassic Black Shales (Lower Jurassic) in the central Upper Rhine Graben. Int J Earth Sci, Germany. https://doi.org/ 10.1007/s00531-015-1188-9

Böcker J, Littke R, Forster A (2016) An overview on source rocks and the petroleum system of the central Upper Rhine Graben. Springer, Berlin

Boggs S, Krinsley D (2006) Application of Cathodoluminescence Imaging to the study of sedimentary rocks. Cambridge University Press

Boiron MC, Cathelineau M, Richard A (2011) Fluid flows and metal deposition near basement/cover unconformity: lessons and analogies from $\mathrm{Pb}-\mathrm{Zn}$-F-Ba systems for the understanding of proterozoic U deposits. Front Geofluids 10:270-292. https://doi.org/10. 1002/9781444394900.ch19

Bons PD, Fusswinkel T, Gomez-Rivas E et al (2014) Fluid mixing from below in unconformity-related hydrothermal ore deposits. Geology 42:1035-1038. https://doi.org/10.1130/G35708.1

Bossennec C, Geraud Y, Moretti I et al (2018) Pore network properties of sandstones in a fault damage zone. J Struct Geol 110:24-44. https://doi.org/10.1016/j.jsg.2018.02.003

Bourgeois O, Ford M, Diraison M et al (2007) Separation of rifting and lithospheric folding signatures in the NW-Alpine foreland. Int J Earth Sci 96:1003-1031. https://doi.org/10.1007/ s00531-007-0202-2

Bourquin S, Peron S, Durand M (2006) Lower Triassic sequence stratigraphy of the western part of the Germanic Basin (west of Black Forest): fluvial system evolution through time and space. Sediment Geol 186:187-211. https://doi.org/10.1016/j.sedgeo. 2005.11.018

Bourquin S, Durand M, Diez JB et al (2007) The permian-triassic boundary and lower triassic sedimentation in western European basins: an overview. J Iber Geol 33:221-236 
Bourquin S, Guillocheau F, Péron S (2009) Braided rivers within an arid alluvial plain (example from the lower triassic, western german basin): recognition criteria and expression of stratigraphic cycles. Sedimentology 56:2235-2264. https://doi.org/10.1111/j. 1365-3091.2009.01078.x

Bourquin S, Bercovici A, López-Gómez J et al (2011) The PermianTriassic transition and the onset of Mesozoic sedimentation at the northwestern peri-Tethyan domain scale: palaeogeographic maps and geodynamic implications. Palaeogeogr Palaeoclimatol Palaeoecol 299:265-280. https://doi.org/10.1016/j.palaeo.2010.11.007

Brigaud B, Bonifacie M, Pagel M et al (2020) Past hot fluid flows in limestones detected by $\Delta 47-(\mathrm{U}-\mathrm{Pb})$ and not recorded by other geothermometers. Geology 48:851-856. https://doi.org/10.1130/ G47358.1

Brockamp O, Clauer N (2005) A km-scale illite alteration zone in sedimentary wall rocks adjacent to a hydrothermal fluorite vein deposit. Clay Miner 40:245-260. https://doi.org/10.1180/00098 55054020170

Brockamp O, Clauer N, Zuther M (2003) Authigenic sericite record of a fossil geothermal system: the Offenburg trough, central Black Forest, Germany. Int J Earth Sci 92:843-851. https://doi.org/10. 1007/s00531-003-0368-1

Brockamp O, Schlegel A, Clauer N (2011) Mesozoic hydrothermal impact on Rotliegende and Bunter immature sandstones of the High Rhine trough and its adjacent eastern area (southern Black Forest, Germany). Sediment Geol 234:76-88. https://doi.org/10. 1016/j.sedgeo.2010.12.001

Brosse É, Matthews J, Bazin B et al (2000) Related Quartz and Illite Cementation in the Brent Sandstones: A Modelling Approach. Quartz Cem Sandstones. https://doi.org/10.1002/9781444304 237.ch4

Burisch M, Gerdes A, Walter BF et al (2017a) Methane and the origin of five-element veins: Mineralogy, age, fluid inclusion chemistry and ore forming processes in the Odenwald, SW Germany. Ore Geol Rev 81:42-61. https://doi.org/10.1016/j.oregeorev.2016. 10.033

Burisch M, Walter BF, Gerdes A et al (2017b) Late-stage anhydritegypsum-siderite-dolomite-calcite assemblages record the transition from a deep to a shallow hydrothermal system in the Schwarzwald mining district, SW Germany. Geochim Cosmochim Acta 223:259-278. https://doi.org/10.1016/j.gca.2017.12.002

Cathelineau M, Fourcade S, Clauer N et al (2004) Dating multistage paleofluid percolations: A K-Ar and 18O/16O study of fracture illites from altered Hercynian plutonites at the basement/cover interface (Poitou High, France). Geochim Cosmochim Acta 68:2529-2542. https://doi.org/10.1016/j.gca.2003.10.037

Cathelineau M, Boiron M-CC, Fourcade S et al (2012) A major Late Jurassic fluid event at the basin/basement unconformity in western France: 40Ar/39Ar and K-Ar dating, fluid chemistry, and related geodynamic context. Chem Geol 322-323:99-120. https://doi.org/10.1016/j.chemgeo.2012.06.008

Cathelineau M, Boiron M-C (2010) Downward penetration and mixing of sedimentary brines and dilute hot waters at $5 \mathrm{~km}$ depth in the granite basement at Soultz-sous-Forêts (Rhine graben, France). Comptes Rendus Geosci 342:560-565. https://doi.org/ 10.1016/j.crte.2009.08.010

Châteauneuf JJ, Ménillet F (2014) A Bartonian microflora record from the Upper Rhine Graben: the Mietesheim formation (Alsace, France). GÉOLOGIE DE LA FRANCE, $\mathrm{N}^{\circ} 13-20$

Clauer N, Liewig N, Ledesert B, Zwingmann H (2008) Thermal history of Triassic sandstones from the Vosges Mountains-Rhine Graben rifting area, NE France, based on K-Ar illite dating. Clay Miner 43:363-379. https://doi.org/10.1180/claymin.2008. 043.3.03

Cloetingh S, Ziegler PA, Beekman F et al (2005) Intraplate deformation and 3D rheological structure of the Rhine Rift System and adjacent areas of the northern Alpine foreland. Int J Earth Sci 94:758-778. https://doi.org/10.1007/s00531-005-0502-3

Cloetingh S, Cornu T, Ziegler P et al (2006) Neotectonics and intraplate continental topography of the northern Alpine Foreland. Earth Sci Rev 74:127-196. https://doi.org/10.1016/j.earscirev. 2005.06.001

Derer CE, Schumacher ME, Schäfer A (2005) The northern upper rhine graben: basin geometry and early syn-rift tectono-sedimentary evolution. Int J Earth Sci 94:640-656. https://doi.org/10.1007/ s00531-005-0515-y

Dezayes C, Lerouge C (2019) Reconstructing paleofluid circulation at the hercynian basement/mesozoic sedimentary cover interface in the upper rhine graben. Geofluids 2019:1-30. https://doi.org/ $10.1155 / 2019 / 4849860$

Dèzes P, Schmid SMM, Ziegler PA (2004) Evolution of the European Cenozoic Rift System: interaction of the Alpine and Pyrenean orogens with their foreland lithosphere. Tectonophysics 389:133. https://doi.org/10.1016/j.tecto.2004.06.011

Dresmann H, Keulen N, Timar-Geng Z et al (2010) The south-western black forest and the upper rhine graben main border fault: thermal history and hydrothermal fluid flow. Int J Earth Sci 99:285297. https://doi.org/10.1007/s00531-008-0391-3

Dubois M, Ougougdal MA, Meere P et al (1996) Temperature of paleoto modern self-sealing within a continental rift basin: the fluid inclusion data (Soultz-sous-Forets, Rhine graben, France). Eur J Mineral 8:1065-1080

Dubois M, Ledésert B, Potdevin J-L, Vançon S (2000) Détermination des conditions de précipitation des carbonates dans une zone d'altération du granite de Soultz (soubassement du fossé Rhénan, France): l'enregistrement des inclusions fluides. Comptes Rendus L'académie Des Sci - Ser IIA - Earth Planet Sci 331:303-309. https://doi.org/10.1016/S1251-8050(00)01429-4

Edel JB, Schulmann K, Rotstein Y (2007) The Variscan tectonic inheritance of the Upper Rhine Graben: evidence of reactivations in the Lias, Late Eocene-Oligocene up to the recent. Int J Earth Sci 96:305-325. https://doi.org/10.1007/s00531-006-0092-8

Eisbacher GH, Fielitz W (2010) Karlsruhe und seine Region - Nordschwarzwald, Kraichgau, Neckartal, südlicher Odenwald, Oberrhein-Graben, Pfälzerwald und westliche Schwäbische Alb., Sammlung g. Schweizerbart Science Publishers

El-Khatri F, El-Ghali MAK, Mansurbeg H et al (2015) Diagenetic alterations and reservoir quality evolution of lower cretaceous fluvial sandstones: Nubian formation, Sirt Basin, north-central Libya. J Pet Geol 38:217-239. https://doi.org/10.1111/jpg.12607

Engelhardt JF, Sudo M, Stockhecke M, Oberhänsli R (2017) Feldspar40Ar/39Ar dating of ICDP PALEOVAN cores. Geochim Cosmochim Acta 217:144-170. https://doi.org/10.1016/j. gca.2017.07.039

Faulkner DR, Jackson CAL, Lunn RJ et al (2010) A review of recent developments concerning the structure, mechanics and fluid flow properties of fault zones. J Struct Geol 32:1557-1575. https://doi. org/10.1016/j.jsg.2010.06.009

Fischer C, Waldmann S, Von Eynatten H (2013) Spatial variation in quartz cement type and concentration: an example from the Heidelberg formation (Teufelsmauer outcrops), Upper Cretaceous Subhercynian Basin, Germany. Sediment Geol 291:4861. https://doi.org/10.1016/j.sedgeo.2013.03.009

Fisher QJ, Casey M, Clennell MB, Knipe RJ (1999) Mechanical compaction of deeply buried sandstones of the North Sea. Mar Pet Geol 16:605-618. https://doi.org/10.1016/S0264-8172(99) 00044-6

Ford M, Carlier Le, de Veslud C, Bourgeois O (2007) Kinematic and geometric analysis of fault-related folds in a rift setting: The Dannemarie basin, Upper Rhine Graben, France. J Struct Geol 29:1811-1830. https://doi.org/10.1016/j.jsg.2007.08.001 
Gardien V, Rabinowicz M, Vigneresse JL et al (2016) Long-lived interaction between hydrothermal and magmatic fluids in the Soultz-sous-Forêts granitic system (Rhine Graben, France). Lithos 246-247:110-127. https://doi.org/10.1016/j.lithos. 2015.12.002

Gloaguen E, Branquet Y, Boulvais P et al (2007) Palaeozoic oolitic ironstone of the French Armorican Massif: a chemical and structural trap for orogenic base metal-As-Sb-Au mineralisation during Hercynian strike-slip deformation. Miner Depos 42:399-422. https://doi.org/10.1007/s00126-006-0120-4

Götte T, Ramseyer K, Pettke T, Koch-Müller M (2013) Implications of trace element composition of syntaxial quartz cements for the geochemical conditions during quartz precipitation in sandstones. Sedimentology 60:1111-1127. https://doi.org/10.1111/ sed.12024

Götze J, Haus R, Prinz S et al (2012) Quartz: deposits. Mineralogy Anal Quartz. https://doi.org/10.1007/978-3-642-22161-3

Haffen S (2012) Caractéristiques géothermiques du réservoir gréseux du Buntsandstein d'Alsace. University of Strasbourg

Haffen S, Géraud Y, Diraison M (2015) Geothermal, structural and petrophysical characteristics of Buntsandstein sandstone reservoir in the Upper Rhine Graben. Proceedings World Geothermal Congress 2015. Melbourne, Australia

Harwood J, Aplin AC, Fialips CI et al (2013) Quartz cementation history of sandstones revealed by high-resolution sims oxygen isotope analysis. J Sediment Res 83:522-530. https://doi.org/10. 2110/jsr.2013.29

Henares S, Caracciolo L, Fern J et al (2016) Diagenetic constraints on heterogeneous reservoir quality assessment: a Triassic outcrop analog of meandering fl uvial reservoirs. Am Assoc Pet Geol Bull 9:1-22. https://doi.org/10.1306/04041615103

Hoefs J, White W, White WM (2015) Stable Isotope Geochemistry. Isot Geochemistry. https://doi.org/10.1007/978-3-319-19716-6

Houseknecht DW (1984) Influence of grain size and temperature on intergranular pressure solution, quartz cementation, and porosity in a quartzose sandstone. J Sediment Res 54:348-361. https://doi. org/10.1306/212F8418-2B24-11D7-8648000102C1865D

Hyodo A, Kozdon R, Pollington AD, Valley JW (2014) Evolution of quartz cementation and burial history of the Eau Claire Formation based on in situ oxygen isotope analysis of quartz overgrowths. Chem Geol 384:168-180. https://doi.org/10.1016/j. chemgeo.2014.06.021

Illies JH (1972) The Rhine Graben rift system - Plate tectonics and transform faulting. Geophys Surv 1:27-60

Kelley SP, Arnaud NO, Turner SP (1994) High spatial resolution 40Ar $39 \mathrm{Ar}$ investigations using an ultra-violet laser probe extraction technique. Geochim Cosmochim Acta 58:3519-3525. https://doi. org/10.1016/0016-7037(94)90103-1

Köppen A, Carter A (2000) Constraints on provenance of the central European Triassic using detrital zircon fission track data. Palaeogeogr Palaeoclimatol Palaeoecol 161:193-204

Kushnir ARL, Heap MJ, Baud P et al (2018) Characterizing the physical properties of rocks from the Paleozoic to Permo-Triassic transition in the Upper Rhine Graben. Geotherm Energy. https://doi. org/10.1186/s40517-018-0103-6

Labaume P, Moretti I (2001) Diagenesis-dependence of cataclastic thrust fault zone sealing in sandstones. Example from the Bolivian Sub-Andean Zone. J Struct Geol 23:1659-1675. https://doi. org/10.1016/S0191-8141(01)00024-4

Lander RH, Bonnell LM (2010) A model for fibrous illite nucleation and growth in sandstones. Am Assoc Pet Geol Bull 94:11611187. https://doi.org/10.1306/04211009121

Lanson B, Beaufort D, Berger G et al (2002) Authigenic kaolin and illitic minerals during burial diagenesis of sandstones: a review. Clay Miner 37:1-22. https://doi.org/10.1180/0009855023710014
Larroque JM, Laurent P (1988) Evolution of the stress field pattern in the south of the Rhine Graben from the Eocene to the present. Tectonophysics 148:41-58. https://doi.org/10.1016/00401951(88)90159-X

Loges A, Wagner T, Kirnbauer T et al (2012) Source and origin of active and fossil thermal spring systems, Northern Upper Rhine Graben, Germany. Appl Geochemistry 27:1153-1169. https:// doi.org/10.1016/j.apgeochem.2012.02.024

Lundegard PD (1992) Sandstone porosity loss; a "big picture" view of the importance of compaction. J Sediment Res 62:250-260. https://doi.org/10.1306/D42678D4-2B26-11D7-8648000102 C1865D

Lutz H, Lorenz V, Engel T et al (2013) Paleogene phreatomagmatic volcanism on the western main fault of the northern Upper Rhine Graben (Kisselwörth diatreme and Nierstein-Astheim Volcanic System, Germany). Bull Volcanol 75:1-11. https://doi.org/10. 1007/s00445-013-0741-2

Mansurbeg H, Morad S, Salem A et al (2008) Diagenesis and reservoir quality evolution of palaeocene deep-water, marine sandstones, the Shetland-Faroes Basin, British continental shelf. Mar Pet Geol 25:514-543. https://doi.org/10.1016/j.marpetgeo.2007.07. 012

Marfil R, Scherer M, Turrero MJ (1996) Diagenetic processes influencing porosity in sandstones from the Triassic Buntsandstein of the Iberian Range, Spain. Sediment Geol 105:203-219. https://doi. org/10.1016/0037-0738(95)00138-7

Mark DF, Parnell J, Kelley SP et al (2005) Geochemistry: Dating of multistage fluid flow in sandstones. Science 309:2048-2051. https://doi.org/10.1126/science.1116034

Mark DF, Parnell J, Kelley SP, Sherlock SC (2006) Temperaturecomposition-time (T-X-t) data from authigenic K-feldspar: an integrated methodology for dating fluid flow events. J Geochemical Explor 89:259-262. https://doi.org/10.1016/j.gexplo.2005. 11.059

McBride EF (1989) Quartz cement in sandstones: a review. EarthScience Rev 26:69-112. https://doi.org/10.1016/0012-8252(89) 90019-6

Merle O, Michon L (2001) The formation of the West European Rift; a new model as exemplified by the Massif Central area. Bulletin de la Société Géologique de France 172(2):213-221. https://doi. org/10.2113/172.2.213

Meulenkamp JE, Sissingh W (2003) Tertiary palaeogeography and tectonostratigraphic evolution of the Northern and Southern Peri-Tethys platforms and the intermediate domains of the African-Eurasian convergent plate boundary zone. Palaeogeogr Palaeoclimatol Palaeoecol 196:209-228. https://doi.org/10.1016/ S0031-0182(03)00319-5

Meyer M, Brockamp O, Clauer N et al (2000) Further evidence for Jurassic mineralizing event in central Europe: K-Ar dating of hydrothermal alternation and fluid inclusion sytematics in wall rocks of the Käfersteige fluorite vein deposit in the northern Black Forest, Germany. Miner Depos 35:754-761. https://doi. org/10.1007/s001260050277

Milovský R, van den Kerkhof A, Hoefs J et al (2012) Cathodoluminescence, fluid inclusion and stable $\mathrm{C}-\mathrm{O}$ isotope study of tectonic breccias from thrusting plane of a thin-skinned calcareous nappe. Int J Earth Sci 101:535-554. https://doi.org/10.1007/ s00531-011-0685-8

Navelot V, Géraud Y, Favier A et al (2018) Petrophysical properties of volcanic rocks and impacts of hydrothermal alteration in the Guadeloupe Archipelago (West Indies). J Volcanol Geotherm Res 360:1-21. https://doi.org/10.1016/j.jvolgeores.2018.07.004

Pfaff K, Hildebrandt LH, Leach DL et al (2010) Formation of the Wiesloch Mississippi Valley-type $\mathrm{Zn}-\mathrm{Pb}-\mathrm{Ag}$ deposit in the extensional setting of the Upper Rhinegraben, SW Germany. Miner Depos 45:647-666. https://doi.org/10.1007/s00126-010-0296-5 
Pollington AD, Kozdon R, Valley JW (2011) Evolution of quartz cementation during burial of the Cambrian Mount Simon sandstone, Illinois Basin: in situ microanalysis of $818 \mathrm{O}$. Geology 39:1119-1122. https://doi.org/10.1130/G32195.1

Reicherter K, Froitzheim N, Jarosiński M et al (2008) Alpine tectonics north of the Alps. Geol Cent Eur 2:1233-1285

Richter DK, Götte T, Götze J, Neuser RD (2003) Progress in application of cathodoluminescence (CL) in sedimentary petrology. Mineral Petrol 79:127-166. https://doi.org/10.1007/ s00710-003-0237-4

Rotstein Y, Schaming M, Rousse S (2005) Tertiary tectonics of the Dannemarie basin, upper Rhine graben, and regional implications. Int J Earth Sci 94:669-679. https://doi.org/10.1007/ s00531-005-0473-4

Rotstein Y, Edel JB, Gabriel G et al (2006) Insight into the structure of the Upper Rhine Graben and its basement from a new compilation of Bouguer Gravity. Tectonophysics 425:55-70. https://doi. org/10.1016/j.tecto.2006.07.002

Roussé S (2006) Architecture et dynamique des séries marines et continentales de l'Oligocène Moyen et Supérieur du Sud du Fossé Rhénan : evolution des milieux de dépôt en contexte de rift en marge de l'avant-pays alpin. Université de Strasbourg

Saigal GC, Morad S (1988) Diagenetic Albitization of Detrital K-feldspar in Jurassic, Lower Cretaceous, and Tertiary Clastic Reservoir Rocks from Offshore Norway, I. Textures and Origin J Sediment Res 58:1003-1013. https://doi.org/10.1306/212F8 EE5-2B24-11D7-8648000102C1865D

Sanjuan B, Millot R, Innocent C et al (2016) Major geochemical characteristics of geothermal brines from the Upper Rhine Graben granitic basement with constraints on temperature and circulation. Chem Geol 428:27-47. https://doi.org/10.1016/j.chemgeo. 2016.02.021

Schleicher AM, Warr LN, Kober B et al (2006) Episodic mineralization of hydrothermal illite in the Soultz-sous-Forêts granite (Upper Rhine Graben, France). Contrib to Mineral Petrol 152:349-364. https://doi.org/10.1007/s00410-006-0110-7

Schmidt RB, Bucher K, Drüppel K, Stober I (2017) Experimental interaction of hydrothermal $\mathrm{Na}-\mathrm{Cl}$ solution with fracture surfaces of geothermal reservoir sandstone of the Upper Rhine Graben. Appl Geochemistry 81:36-52. https://doi.org/10.1016/j.apgeochem. 2017.03.010

Schmidt C, Busch B, Hilgers C (2020) Compaction and cementation control on bleaching in Triassic fluvial red beds, S-Germany. Zeitschrift Der Dtsch Gesellschaft Für Geowissenschaften. https://doi.org/10.1127/zdgg/2020/0233

Schumacher ME (2002) Upper Rhine Graben: role of preexisting structures during rift evolution. Tectonics. https://doi.org/10.1029/ 2001TC900022

Schwinn G, Wagner T, Baatartsogt B, Markl G (2006) Quantification of mixing processes in ore-forming hydrothermal systems by combination of stable isotope and fluid inclusion analyses. Geochim Cosmochim Acta 70:965-982. https://doi.org/10.1016/j. gca.2005.10.022

Sharp ZD, Gibbons JA, Maltsev O et al (2016) A calibration of the triple oxygen isotope fractionation in the $\mathrm{SiO} 2-\mathrm{H} 2 \mathrm{O}$ system and applications to natural samples. Geochim Cosmochim Acta 186:105-119. https://doi.org/10.1016/j.gca.2016.04.047

Sissingh W (1998) Comparative tertiary stratigraphy of the Rhine Graben, Bresse Graben and Molasse Basin: correlation of Alpine foreland events. Tectonophysics 300:249-284. https://doi.org/10. 1016/S0040-1951(98)00243-1

Sizun J-P (1995) Modifications des structures de porosité de grès lors de transformations pétrographiques dans la diagenèse et l'hydrothermalisme: application au Trias de la marge ardéchoise et du fossé rhénan. Université Louis Pasteur de Strasbourg
Smith MP, Savary V, Yardley BWD et al (1998) The evolution of the deep flow regime at Soultz-sous-Forêts, Rhine Graben, eastern France: evidence from a composite quartz vein. J Geophys Res 103:27223-27237. https://doi.org/10.1029/98jb02528

Sokol G, Nitsch E, Anders B, et al (2013) Geopotenziale des tieferen Untergrundes im Oberrheingraben, Fachlich-Technischer Abschlussbericht des INTERREG-ProjektS GeORG, Teil 1. Freiburg

Soyk D (2015) Diagenesis and reservoir quality of the Lower and Middle Buntsandstein (Lower Triassic). Ruprecht-Karls-Universität Heidelberg, SW Germany

Staude S, Bons PD, Markl G (2009) Hydrothermal vein formation by extension-driven dewatering of the middle crust: an example from SW Germany. Earth Planet Sci Lett 286:387-395. https:// doi.org/10.1016/j.eps1.2009.07.012

Staude S, Mordhorst T, Nau S et al (2012) Hydrothermal carbonates of the Schwarzwald ore district, southwestern Germany: carbon source and conditions of formation using delta18O, delta13C, 87Sr/86Sr, and fluid inclusions. Can Mineral 50:1401-1434. https://doi.org/10.3749/canmin.50.5.1401

Tartèse R, Poujol M, Gloaguen E et al (2015) Hydrothermal activity during tectonic building of the Variscan orogen recorded by $\mathrm{U}-\mathrm{Pb}$ systematics of xenotime in the Grès Armoricain formation, Massif Armoricain, France. Mineral Petrol 109:485-500. https://doi. org/10.1007/s00710-015-0373-7

Therkelsen J (2016) Diagenesis and reservoir properties of middle Jurassic sandstones, Traill $\varnothing$, East Greenland: The influence of magmatism and faulting. Mar Pet Geol 78:196-221. https://doi. org/10.1016/j.marpetgeo.2016.09.017

Timar-Geng Z, Fügenschuh B, Wetzel A, Dresmann H (2006) Lowtemperature thermochronology of the flanks of the southern Upper Rhine Graben. Int J Earth Sci 95:685-702. https://doi. org/10.1007/s00531-005-0059-1

Tournier F (2010) Mécanismes et contrôle des phénomènes diagénétiques en milieu acide dans les grès de l'Ordovicien glaciaire du bassin de Sbaa, Algérie

Tournier F, Pagel M, Portier E et al (2010) Relationship between deep diagenetic quartz cementation and sedimentary facies in a late ordovician glacial environment (Sbaa Basin, Algeria). J Sediment Res 80:1068-1084. https://doi.org/10.2110/jsr.2010.094

Uto K, Ishizuka O, Matsumoto A et al (1997) Laser-heating 40Ar/39 Ar dating system of the Geological Survey of Japan: system outline and preliminary results. Bull Geol Surv Japan 48:23-46

Valley JW, Graham CM (1996) Ion microprobe analysis of oxygen isotope ratios in quartz from Skye granite: healed micro-cracks, fluid flow, and hydrothermal exchange. Contrib to Mineral Petrol 124:225-234. https://doi.org/10.1007/s004100050188

Vidal J, Genter A (2018) Overview of naturally permeable fractured reservoirs in the central and southern Upper Rhine Graben: insights from geothermal wells. Geothermics 74:57-73. https:// doi.org/10.1016/J.GEOTHERMICS.2018.02.003

Walderhaug O (1994) Precipitation rates for quartz cement in sandstones determined by fluid inclusion microthermometry and temperature-history modelling. J Sediment Res 64A:324-333. https://doi.org/10.2110/jsr.64.324

Walter BF, Burisch M, Markl G (2016) Long-term chemical evolution and modification of continental basement brines - a field study from the Schwarzwald, SW Germany. Geofluids 16:604-623. https://doi.org/10.1111/gfl.12167

Walter BF, Burisch M, Fusswinkel T et al (2018) Multi-reservoir fluid mixing processes in rift-related hydrothermal veins, Schwarzwald, SW-Germany. J Geochemical Explor 186:158-186. https://doi.org/10.1016/j.gexplo.2017.12.004

Walter BF, Kortenbruck P, Scharrer M et al (2019) Chemical evolution of ore-forming brines-Basement leaching, metal provenance, and the redox link between barren and ore-bearing hydrothermal 
veins. A case study from the Schwarzwald mining district in SWGermany. Chem Geol 506:126-148. https://doi.org/10.1016/j. chemgeo.2018.12.038

Wilkinson JJ (2001) Fluid inclusions in hydrothermal ore deposits. Lithos 55:229-272. https://doi.org/10.1016/S0024-4937(00) 00047-5

Worden RH, Burley SD (2003) Sandstone Diagenesis: The Evolution of Sand to Stone. International Association of Sedimentologists

Worden RH, Morad S (2000) Quartz cementation in oil field sandstones: a review of the key controversies. Quartz Cem Sandstones. https://doi.org/10.1002/9781444304237.ch1

Xi K, Cao Y, Jahren J et al (2015) Quartz cement and its origin in tight sandstone reservoirs of the Cretaceous Quantou formation in the southern Songliao basin, China. Mar Pet Geol 66:748-763. https://doi.org/10.1016/j.marpetgeo.2015.07.017

Yang XS (2000) Modeling mineral reactions in compacting sedimentary basins. Geophys Res Lett 27:1307-1310. https://doi.org/10. 1029/1999GL010998

Yuan G, Cao Y, Gluyas J et al (2015) Feldspar dissolution, authigenic clays and quartz cements in open and closed geochemical systems during diagenesis: typical examples from two rift sags in Bohai Bay Basin, East China. Am Assoc Pet Geol Bull 99:21212154. https://doi.org/10.1306/07101514004

Yuan G, Cao Y, Gluyas J et al (2017) Petrography, fluid inclusion, isotope and trace element constraints on the origin of quartz cementation and feldspar dissolution and the associated fluid evolution in arkosic sandstones. Am Assoc Pet Geol Bull 170:165. https://doi.org/10.1306/0608171616017066

Zhu H, Zhong D, Yao J et al (2015) Alkaline diagenesis and its effects on reservoir porosity: a case study of Upper Triassic Chang 7 Member tight sandstone in Ordos Basin, NW China. Pet Explor Dev 42:56-65. https://doi.org/10.1016/S1876-3804(15)60006-4

Ziegler PA (1992) European Cenozoic rift system. Tectonophysics 208:91-111. https://doi.org/10.1016/0040-1951(92)90338-7

Ziegler P, a. (1990) Collision related intra-plate compression deformations in Western and Central Europe. J Geodyn 11:357-388. https://doi.org/10.1016/0264-3707(90)90017-O

Ziegler PA, Cloetingh S, van Wees J-D (1995) Dynamics of intraplate compressional deformation: the Alpine foreland and other examples. Tectonophysics 252:7-59. https://doi.org/10.1016/ 0040-1951(95)00102-6

Ziegler PA, Dèzes P, Ziegler PA, Dèzes P et al (2007) Cenozoic uplift of variscan massifs in the alpine foreland: timing and controlling mechanisms. Glob Planet Change 58:237-269. https://doi.org/10. 1016/j.gloplacha.2006.12.004

Zwingmann H, Clauer N, Gaupp R (1999) Structure-related geochemical (REE) and isotopic (K-Ar, Rb-Sr, $818 \mathrm{O}$ ) characteristics of clay minerals from Rotliegend sandstone reservoirs (Permian, northern Germany). Geochim Cosmochim Acta 63:2805-2823. https://doi.org/10.1016/S0016-7037(99)00198-2 